\title{
مقاصد القرآن الكريم في بناء الحضارة والعمران عند المعاصرين
}

$$
\begin{aligned}
& \text { ماهر حسين حصوة } \\
& \text { الملخص } \\
& \text { تتناول هذه الورقة الجهود التي بذها المفكرون المعاصرون من أجل بيان مقاصد القرآن الكريم في بناء الحضارة }
\end{aligned}
$$

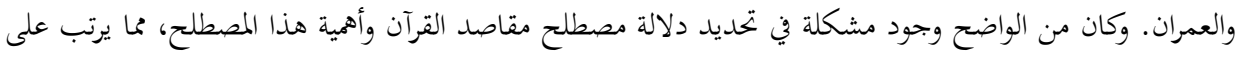

$$
\begin{aligned}
& \text { هؤلاء المفكرين مسؤولية الوصول إلى قدر من التوافق على تحديد المقاصد الأساسية للقرآن الكريم ودورها في تقويم }
\end{aligned}
$$

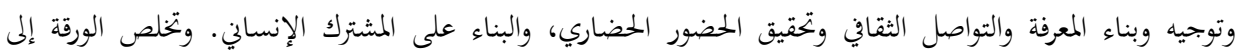

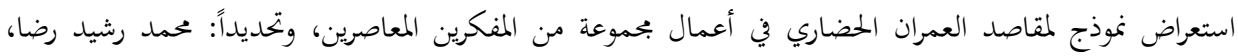

$$
\begin{aligned}
& \text { والطاهر بن عاشور، وعلال الفاسي، وسيد قطب، وأحمد الريسوني. } \\
& \text { الكلمات المفتاحية: مقاصد القرآن، البناء الحضاري، العمران، الفكر الحضاري. }
\end{aligned}
$$

\section{Intents (Maqasid) of the Gracious Qur'an in Building Civilization and$$
\text { Development }
$$$$
\text { Maher Haswah }
$$$$
\text { Abstract }
$$

This paper deals with the efforts exerted by modern scholars to clarify the intents and purposes (Maqasid) of the Gracious Qur'an in building civilization and development. It was clear that there is a problem in determining the meaning of this concept and its significance, which call upon scholars to discuss and make some consensus in identifying the basic intents of the Qur'an and their role in the evaluation, guidance, knowledge building, the cultural linkages, the civilizational take off, the achievement of civilizational presence and building on human commonalities.

The paper concludes with reviewing a model of the intent of building civilization (Umran), as it pertains to civilizational thought addressed by certain contemporary scholars, specifically: Muhammad Rashid Rida, Al-Tahir Ibn Ashour, Allal Al-Fassi, Sayyid Qutb and Ahmad Al-Rissouni.

Keywords: Intents of the Qur'an (Maqasid), Civilizational building, Umran (Civilization), Civilizational thought.

دكتوراه في الفقه وأصوله، الجامعة الأردنية، ج . . ب بم، أستاذ مشارك للفقه وأصوله في كلية القانون بجامعة العين للعلوم

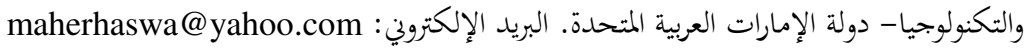

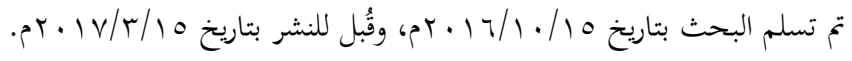




\section{مقدمة:}

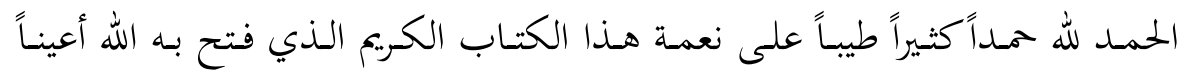

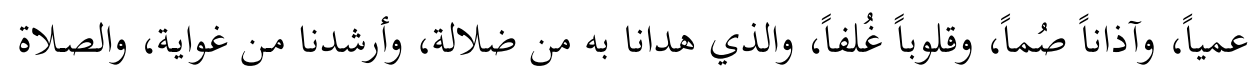

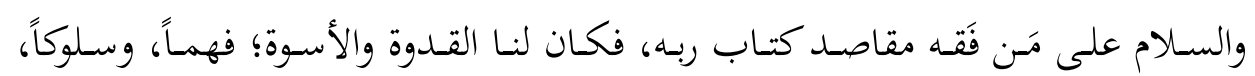
ومنهجاً.

يشتمل البحث على ثلاثة أقسام رئيسة، أولها يحمل عنوان: "تعريف مقاصد القرآن

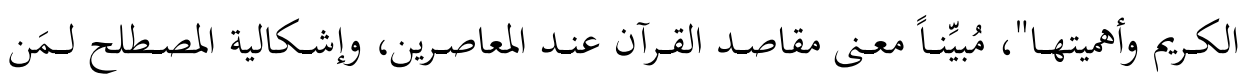

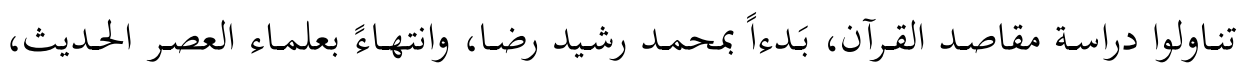

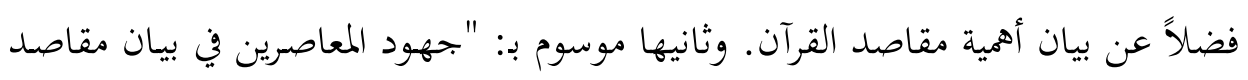

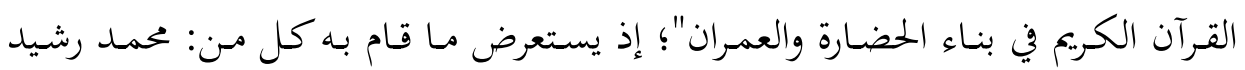

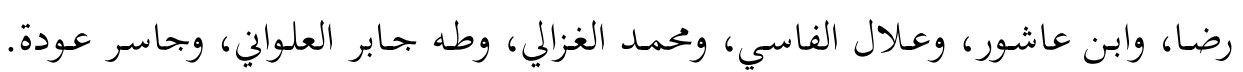

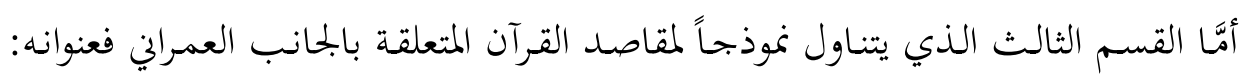

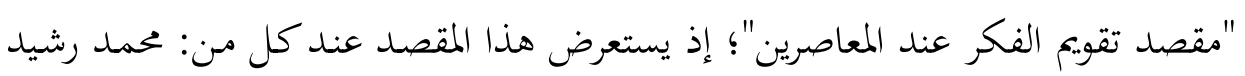
رضا، وابن عاشور، وعلال الفاسي، وسيد قطب، وأحمد الريسوني.

ويهدف البحث إلى إبراز جهود المعاصرين في بيان مقاصد القرآن الكريع، ولا سيما

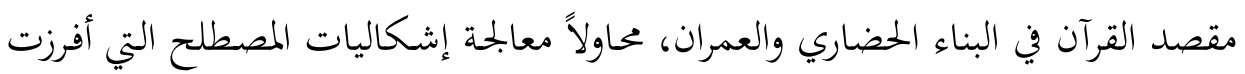

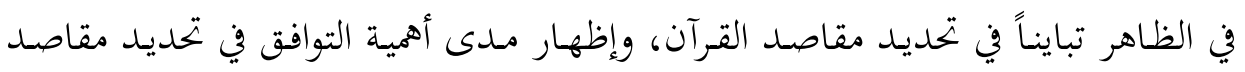

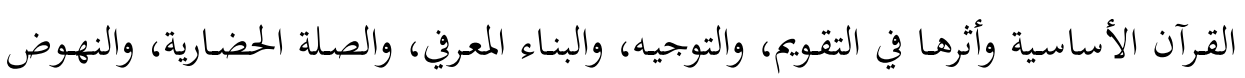
العمراني، وتحقيق الشهود الحضاري والمشترك الإنساني.

حظي موضوع مقاصد الشريعة باهتمام كبير من المعاصرين، وقد تمثل ذلك في في إنشاء

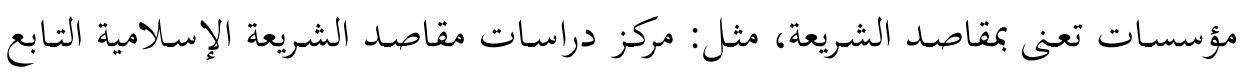

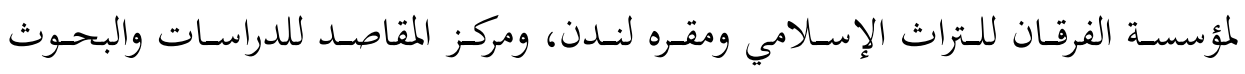

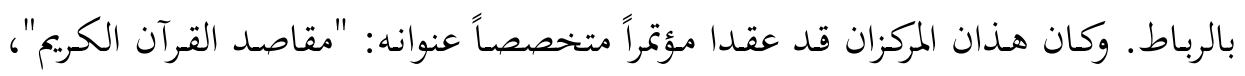

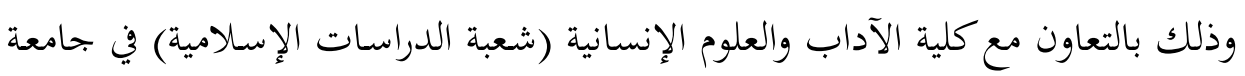




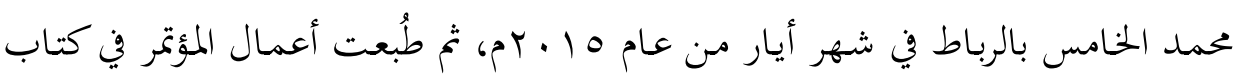

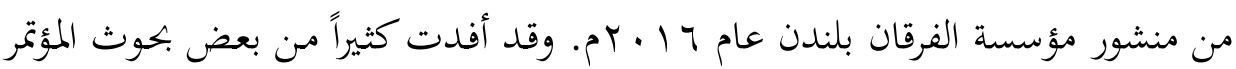

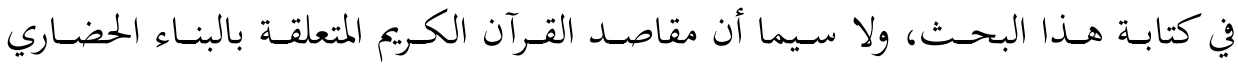

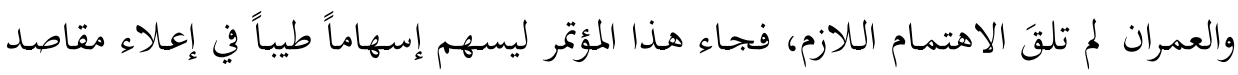

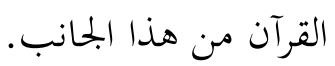

ويمزج البحث بين كل من: المنهج الاستقرائي، والوصفي، والتحليلي، محاولاً تحديد المعالم الرئيسة التي تُلخِّص توجه المعاصرين لدى استعراضهم مقاصد القرآن الكريم المتعلقة

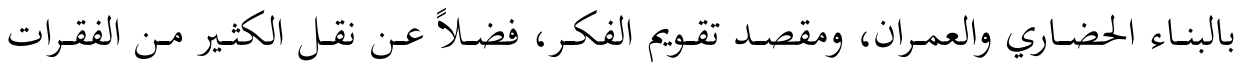
المنتقاة من أقوالهم فيما سُطر من كتبهم، وهي بالعشرات، لتأكيد تلك المعالم التي أفرزها

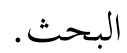

\section{أولاً: تعريف مقاصد القرآن الكريم وأهميتها}

\section{I ـ تعريفات المعاصرين لمصطلح "مقاصد القرآن":}

عرَّف عبد الكريم حامـدي هـذا المصطلح الذي وافقـه عليه أحمد الريسولي، قائلاً:

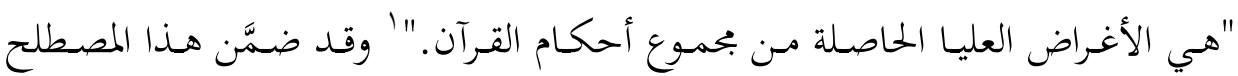

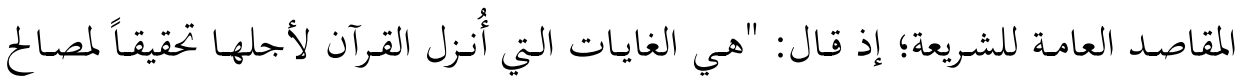

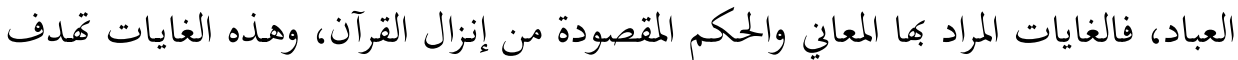

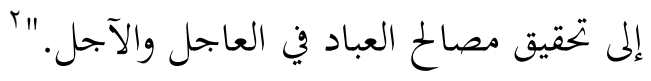

أمَّـا هيـا ثـامر مفتـاح فعرَّفتهـه بأنـه: "الثمـرات العامـة، والأهــاف الكليـة، والغايـات

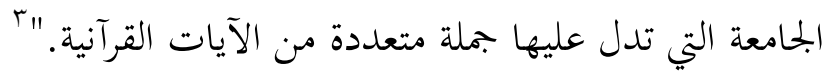

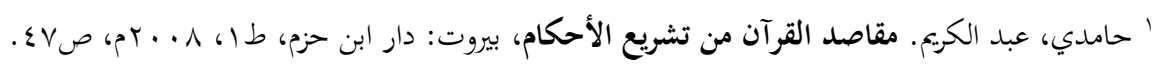

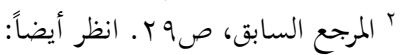

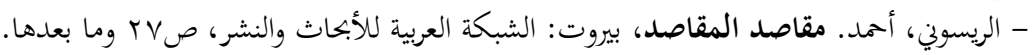

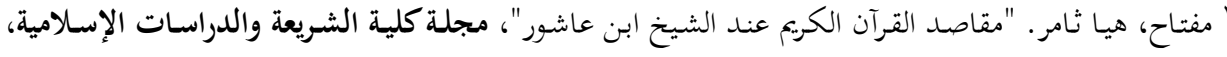




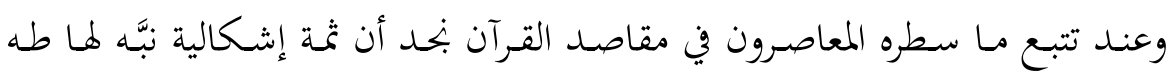

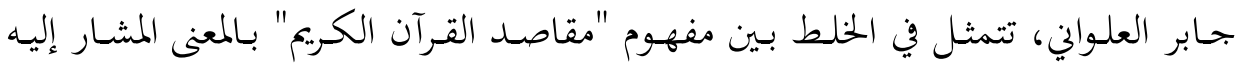

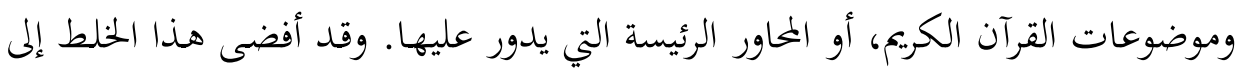

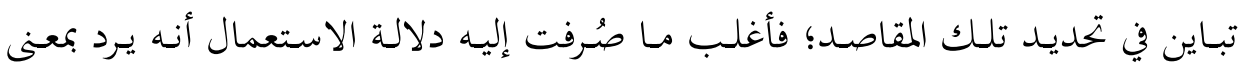

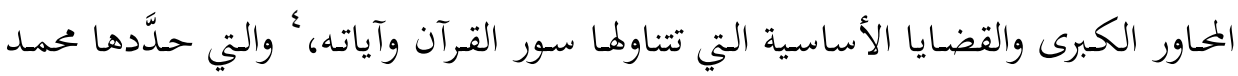

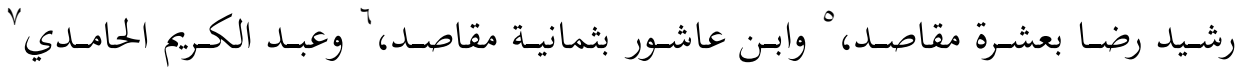

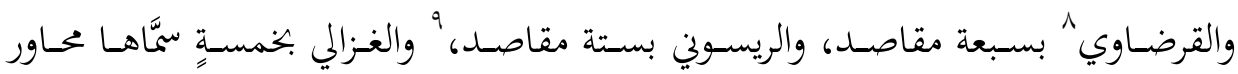

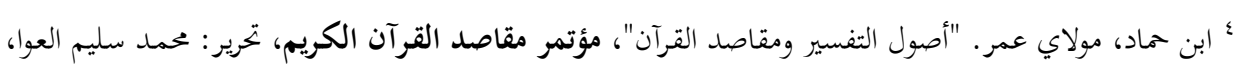

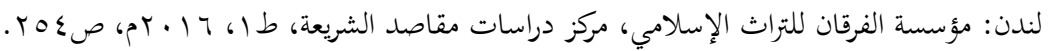

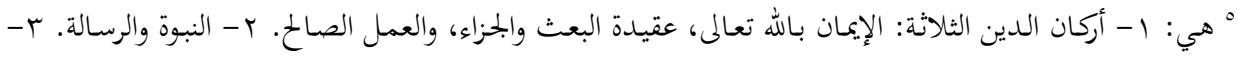

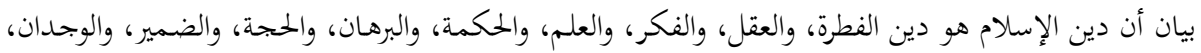

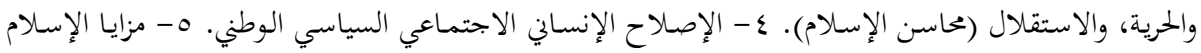

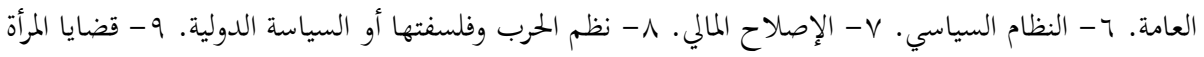

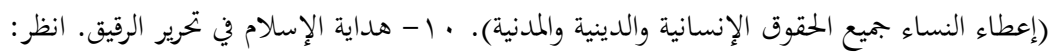

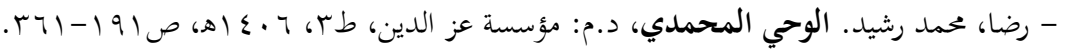

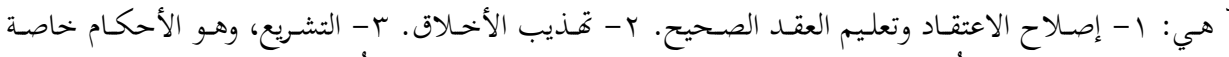

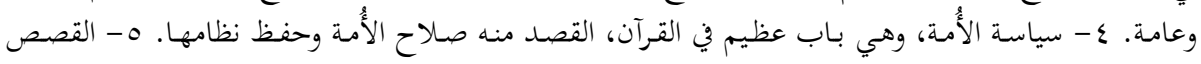

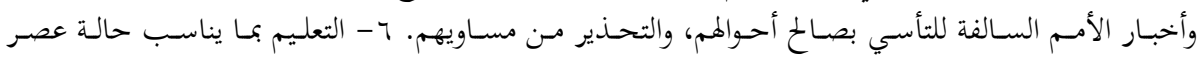

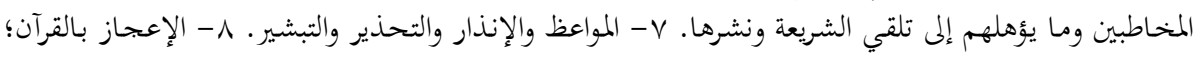

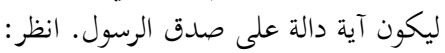

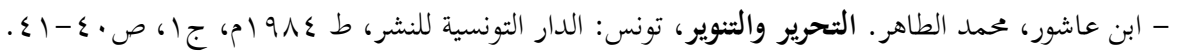

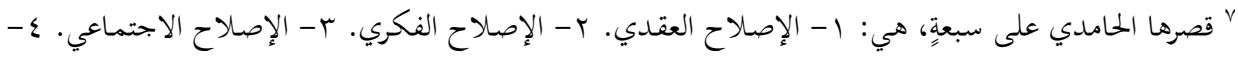

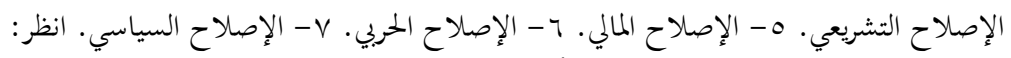

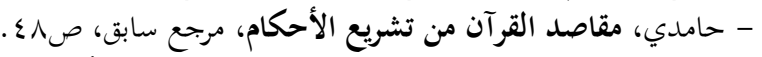

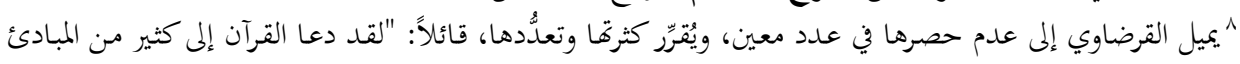

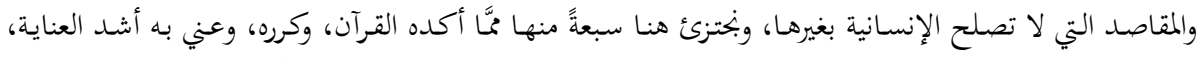

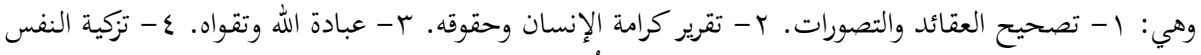

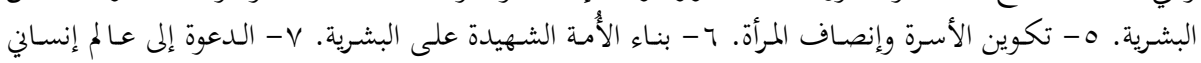

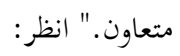

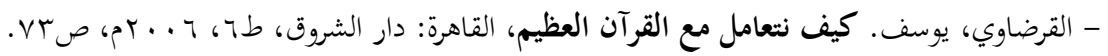

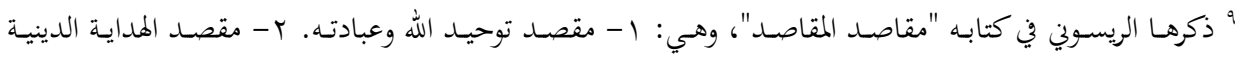

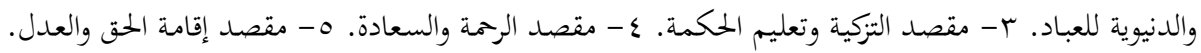

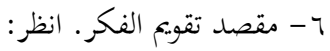




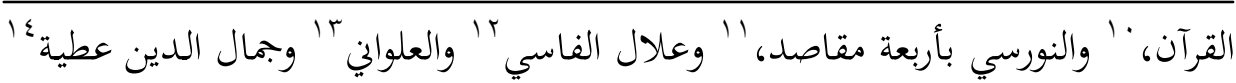

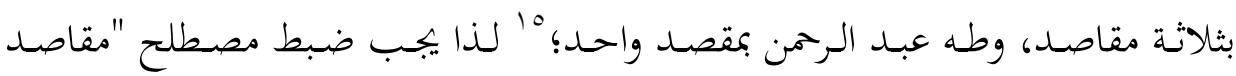
القرآن" بوصفه مصطلحاً، بتحنباً للخلط في الاستعمال.

ولعل التباين في تحديد عدد مقاصد القرآن الكريم يعزى إلى أسباب عدَّة، منها: - عدم استقرار دلالة المصطلح إبان تناوله من المعاصرين؛ فقد أطلق بعضهم على

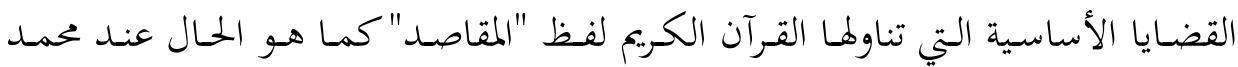
رشيد رضا.

- اجتهاد العالِم في دمج مقاصد عدَّة ضمن محور واحد، أو مقصد واحلد يتفرع منه مقاصد علدَّة؛ ما قد يبعله منطلقاً لتفريعات متعلددة.

- الريسوني، مقاصد المقاصد، مرجع سابق، صر ب وما بعدها.

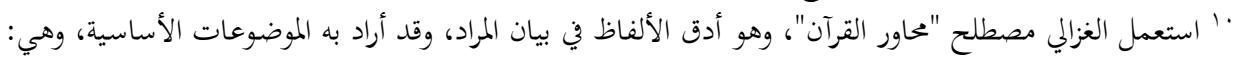

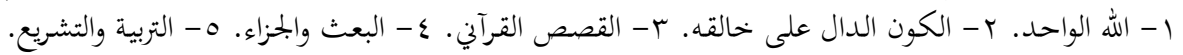

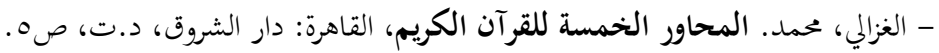

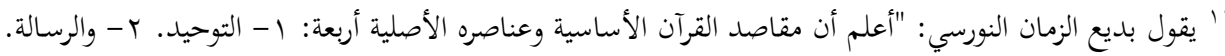

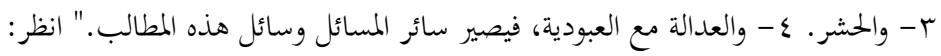

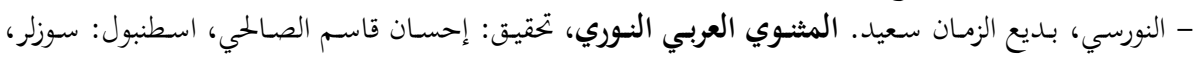

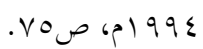
- النورسي، بديع الزمان سعيد. إشارات الإعجاز في مظان الإيجاز، ترجمة: إحسان قاسم الصالحي، القاهرة:

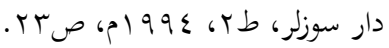

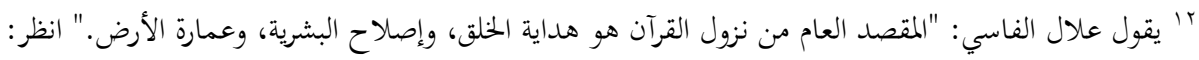

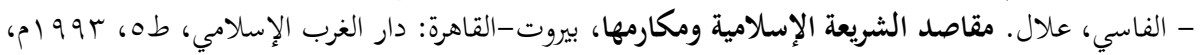
ص11.

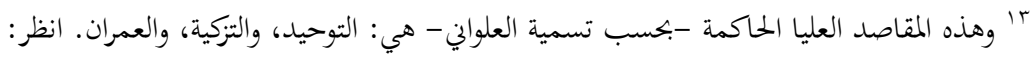

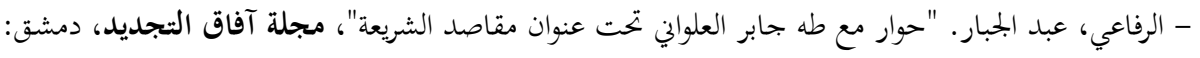

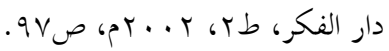

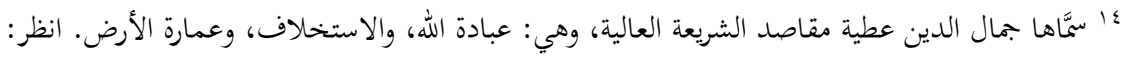

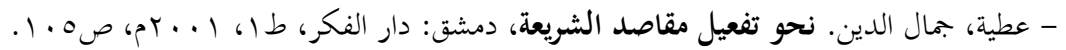

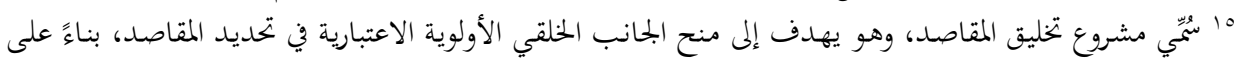

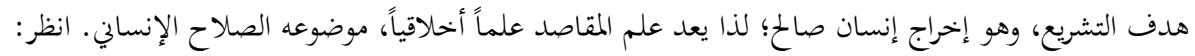

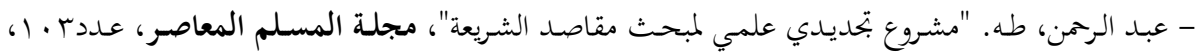




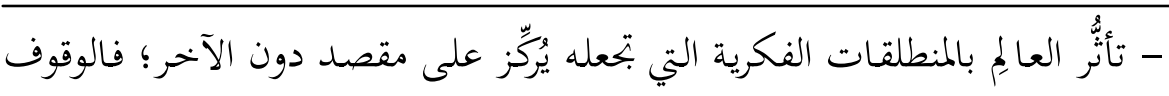

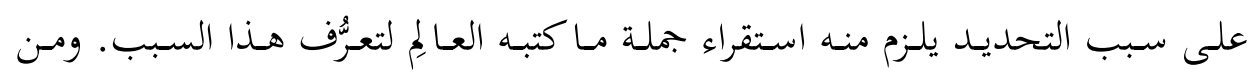

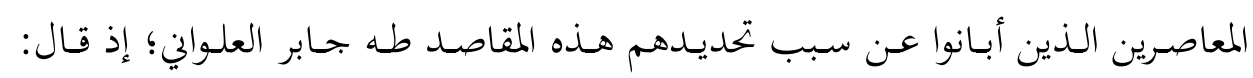

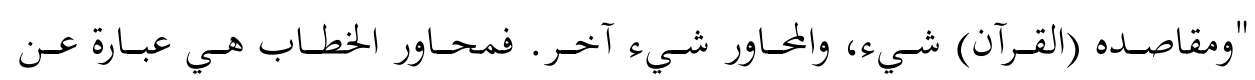

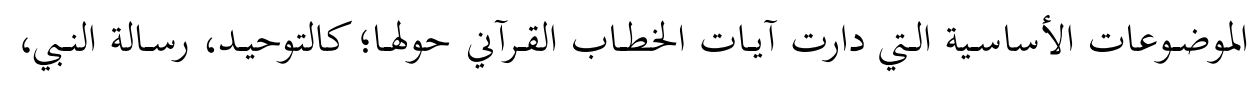

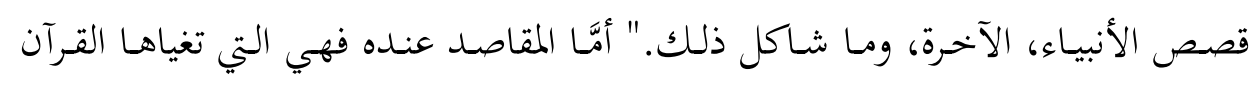

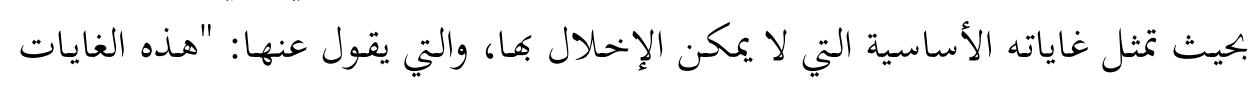

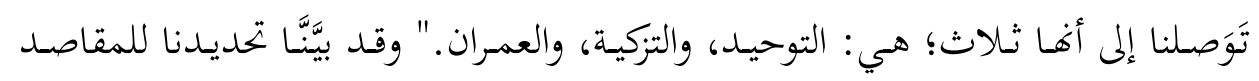

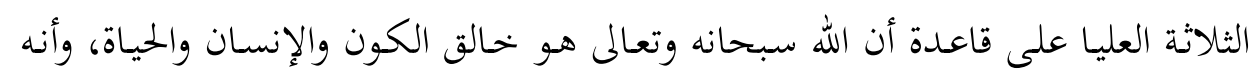

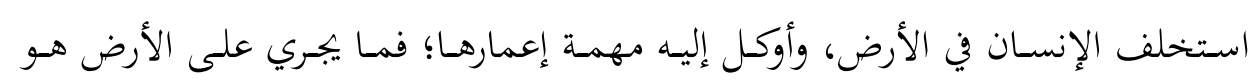

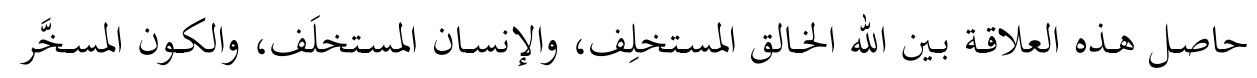

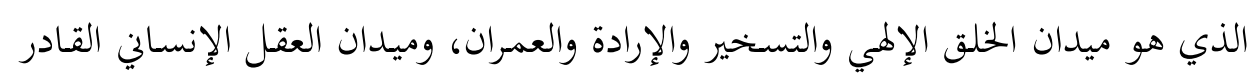

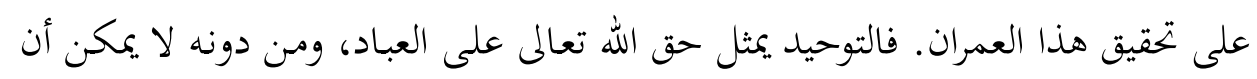
يتحقق شيء من المنظومة كلها، وهو يمثل أيضاً القصد الأعلى من رسالات الألى الأنبياء كافة.

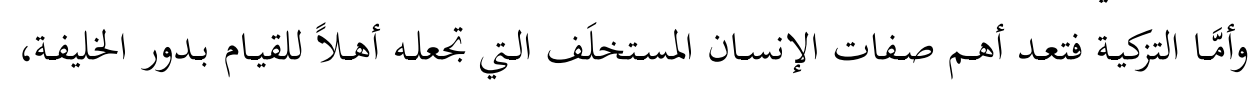

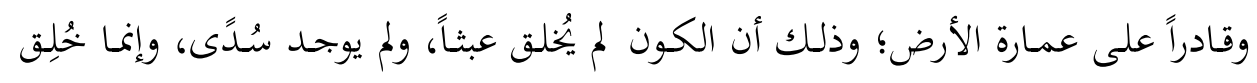

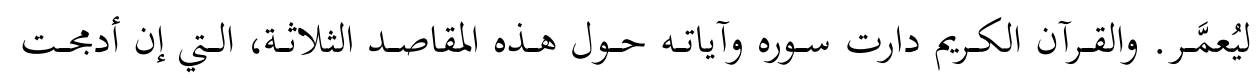

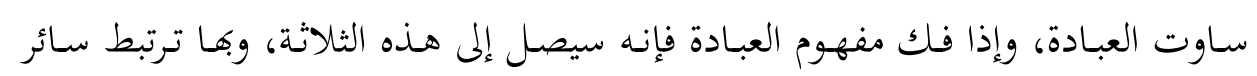

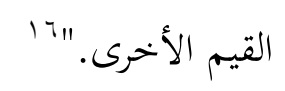

ويرى جاسر عودة -بعد أن استعرض مقاصد القرآن الكريم عند محمد رشيد رضا

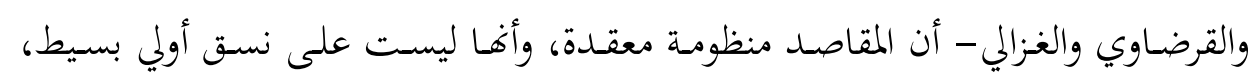

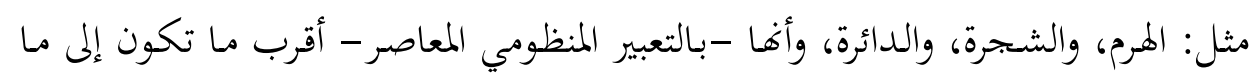

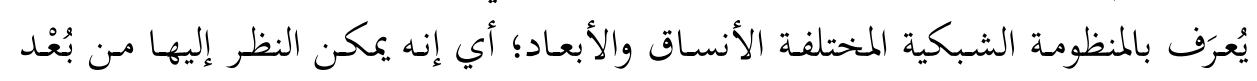

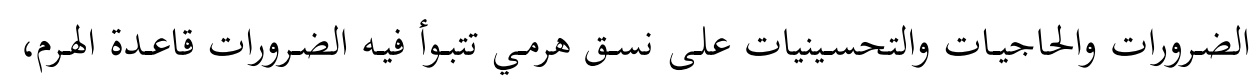




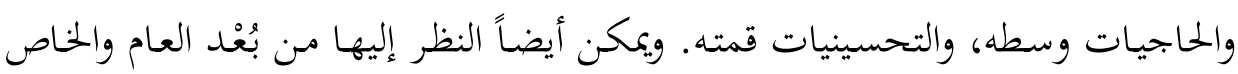

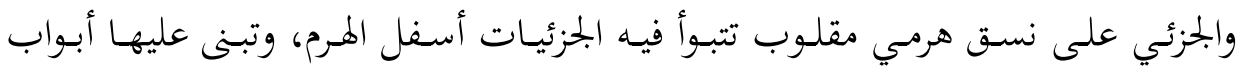

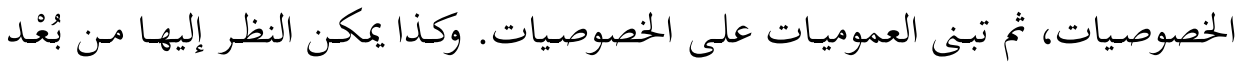

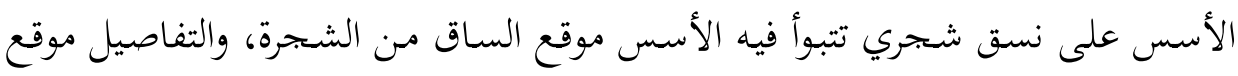

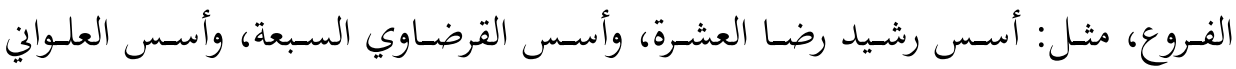

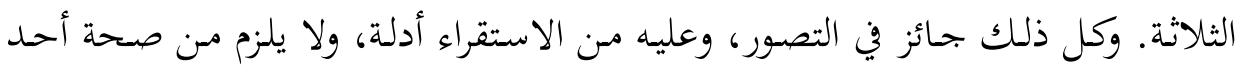

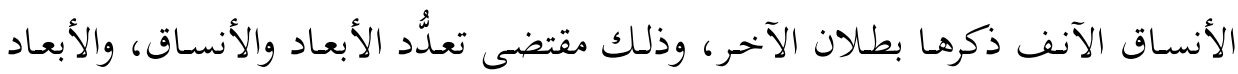

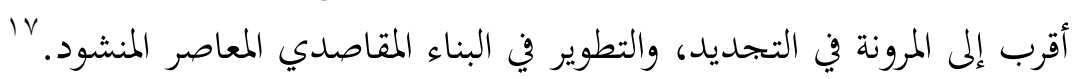

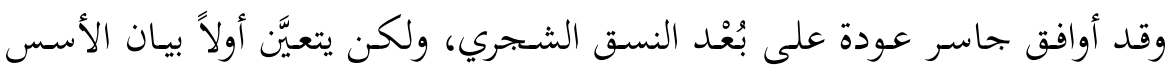

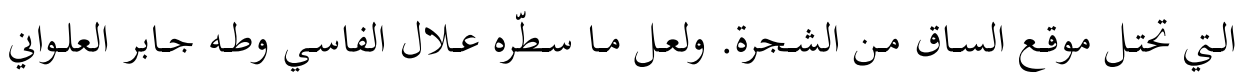

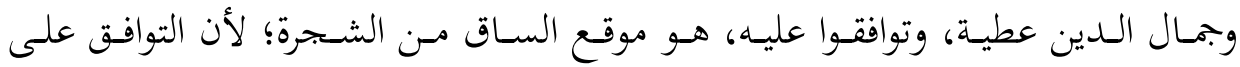

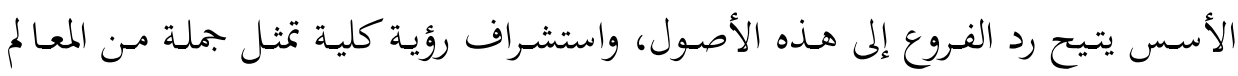

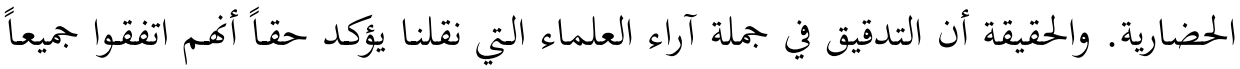

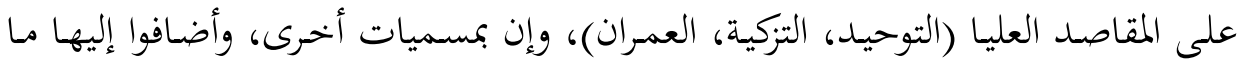

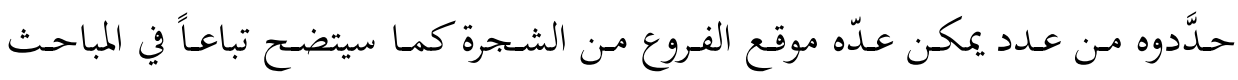

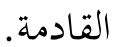

\section{Y. أهمية مقاصد القرآن الكريم:^^ يمكن إجمال أهمية هذه المقاصد فيما يأتي:}

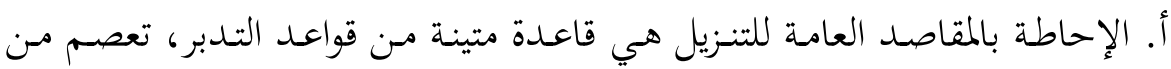

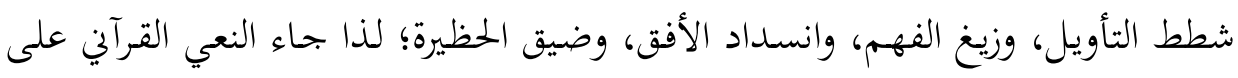
لا عودة، جاسر ـ الاجتهاد المقاصدي من التصور الأصولي إلى التنزيل العملي، بيروت: الشبكة العربية للأبحاث

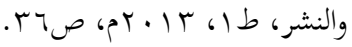

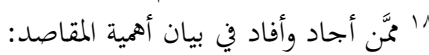

- الريسوني، قطب. النص القرآني مـ تهافت القان القراءة إلى أفق التدبر، المغرب: وزارة الأوقاف والشؤون

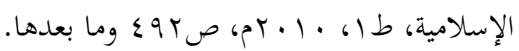

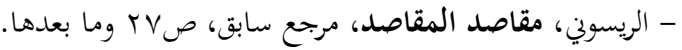

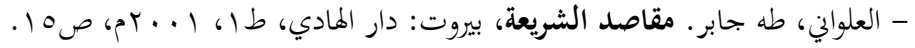




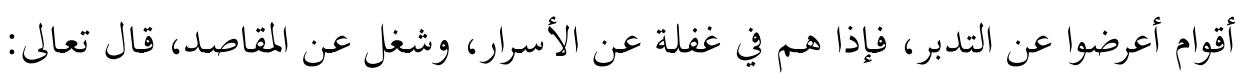

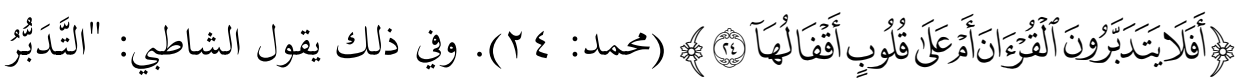

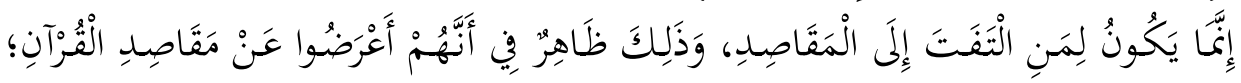

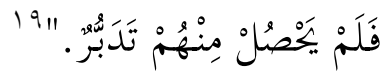

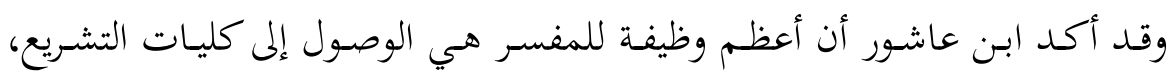

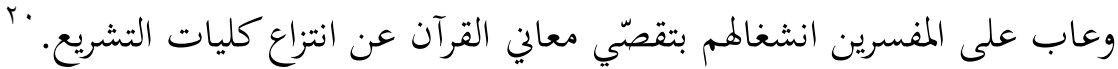

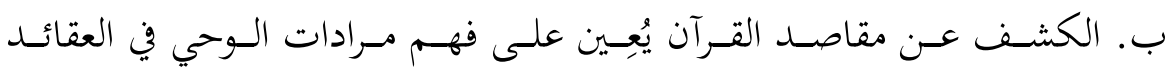

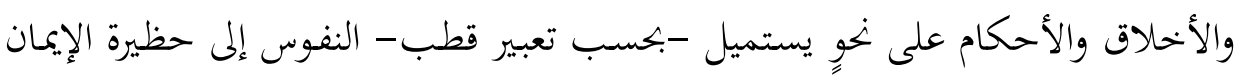

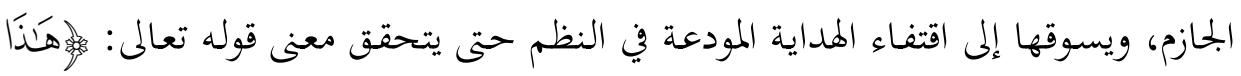

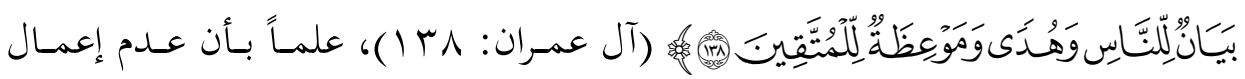

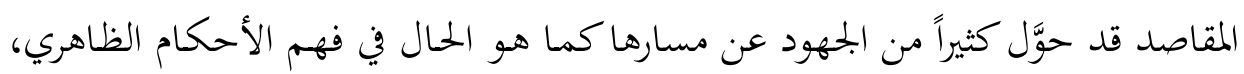
والفهم الفلسفي الجدلي الكلامي في العقائد والأخلاق.

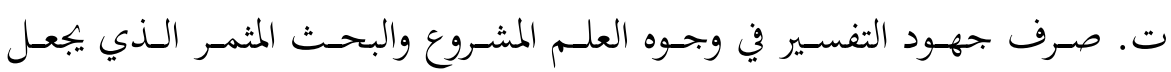

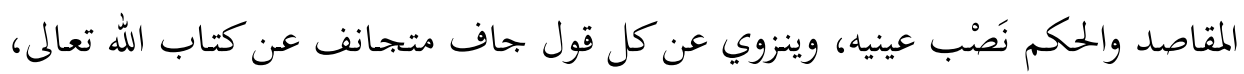

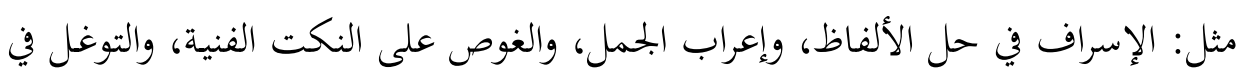

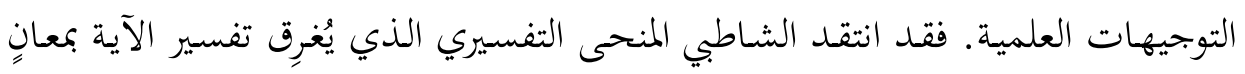

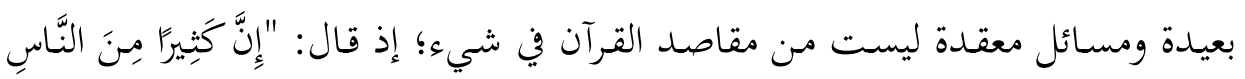

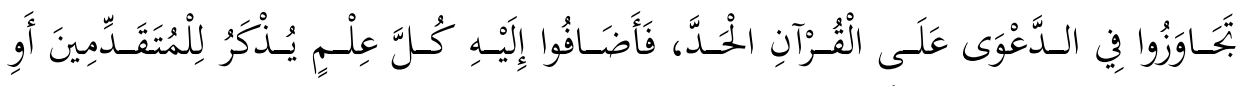

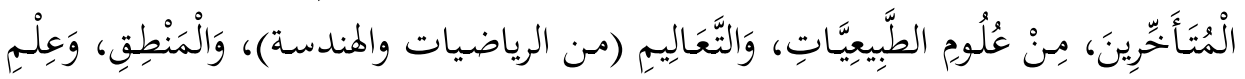

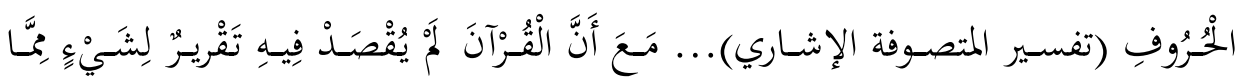

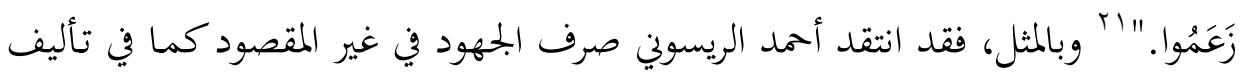

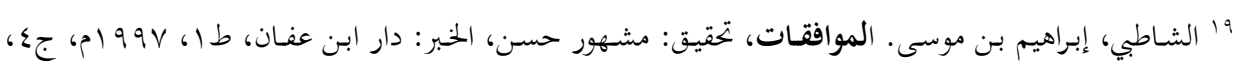

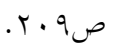

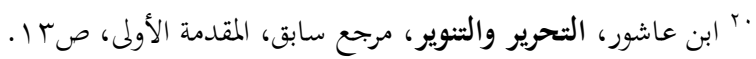

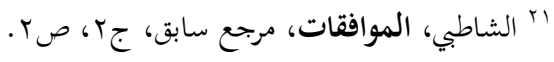


كتب عن مبهمات القرآن، فقال: "الاشتغال بغير المقصود إعراض عن المقصود.... ومن

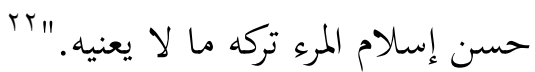

ث. وضــع الأحكـام القرآنيـة في سـياقها العـام ونصـابها الصـحيح، وحســم مـادة

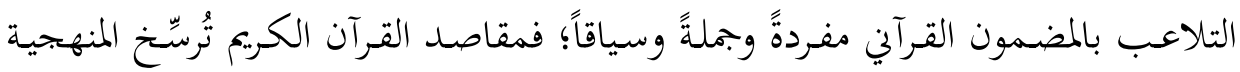

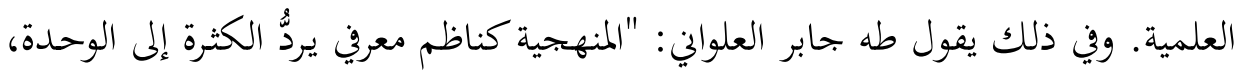

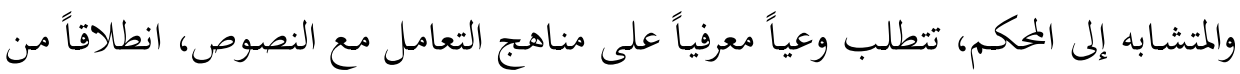

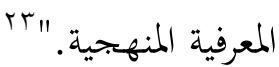

ج. صياغة تصور شامل عن مقاصد التنزيل الكلية لكي تكون مرجعاً حاكماً على فهم القرآن كله؛ وذلك أن من أصول التدبر إرجاع مقاصد السور والمقاطع والآيات إلى

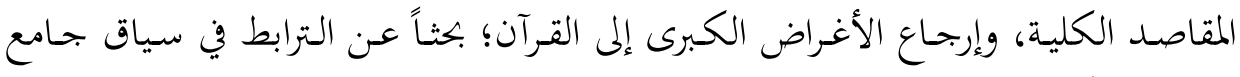
ناظم، تُشَدُُّ إليه الروابط القرآنية من كل حداع الاغراض لحسب وصوب. وتأسيساً على ذلك، فقد حذَّر القرآن الكريم من القراءة التشتيتية التي تُفقِد النص

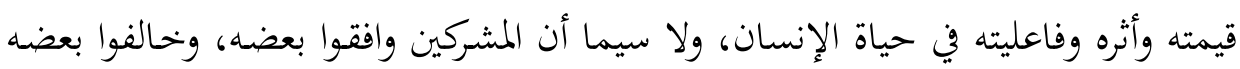

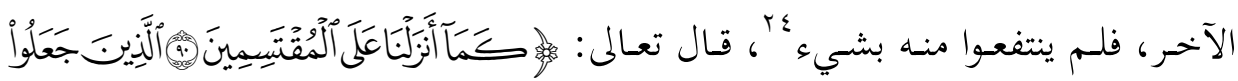

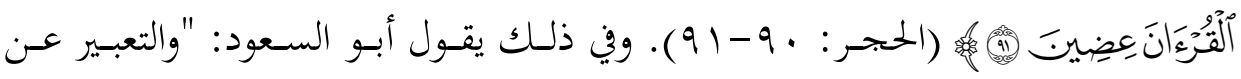

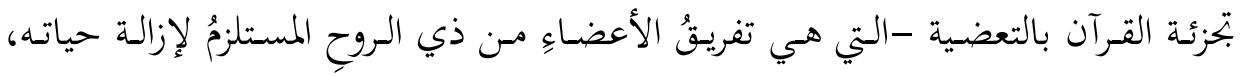

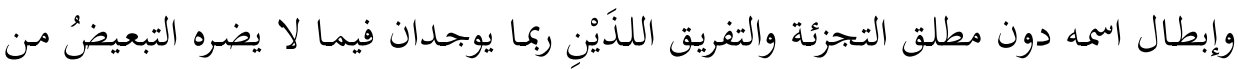

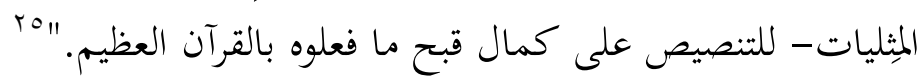

وهـذا التصـور الشـامل لمقاصـد القـرآن يُعِين على تحديـد رؤيـة كليـة كونيـة حضـارية توصل رسالة القرآن والإسلام إلى الناس؛ فقد اجتهد عبد الحميد أبو سليمان -انطلاقاً

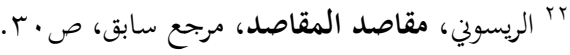

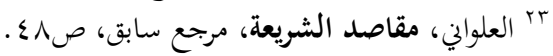

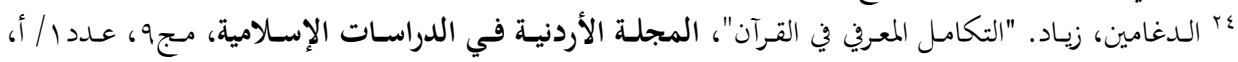

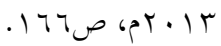
or أبو السعود، عممد بن محمد. تفسير أبي السعود (إرشاد العقل السليم إلى مزايا القرآن الكريم)، بيروت: دار 
من مقاصد القرآن الكريم- في بيـان الرؤيـة الكونية القرآنيـة الحضـارية، قائلاً: "إن الرؤيـة

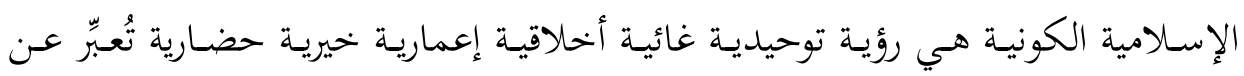
الفطرة الإنسانية السوية، وهي بذلك، وبالضرورة، رؤية علمية سننية تسخيرية تهدف إلى إلى

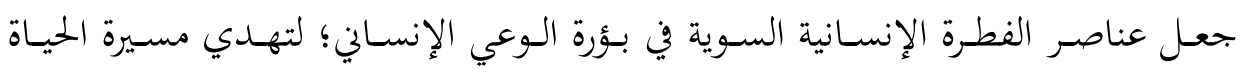

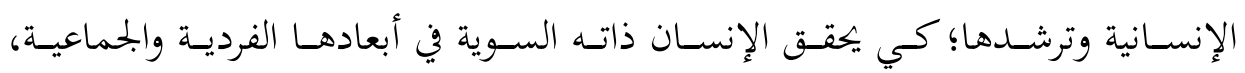

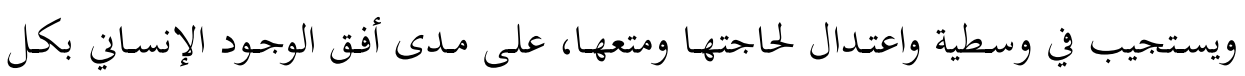

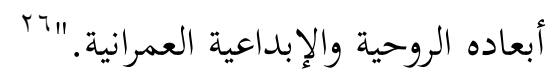

وهذه الرؤية تُحِّدد طبيعة رؤية المسلم للعالم، وكذا طبيعة التعامل مع الآخرين. يقول

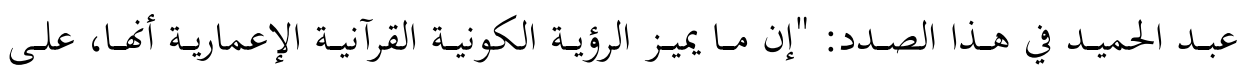
العكس مـن الرؤيـة الماديـة العدوانيـة العنصـرية، بتعـل مـن الاخهتلاف والتمـايز الإنسـاني

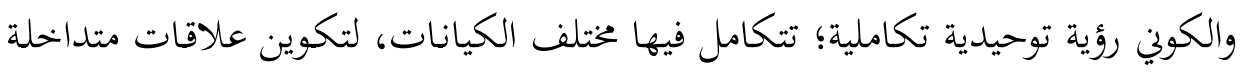

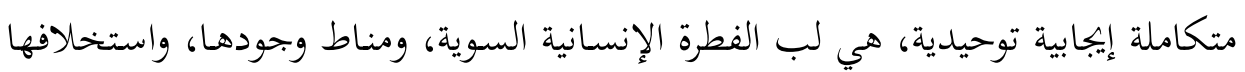
في الأرض، فلا بحال فيها للمغالاة الفردية، ولا للتطرف الجماعي، بل هي في كل أبعادها

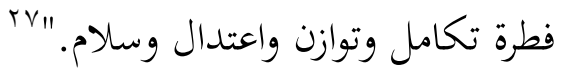

ح. مقاصد القرآن تبدو أشبه بالمبادئ الدستورية، وأساساً للنموذج المعرفي، ويمكن

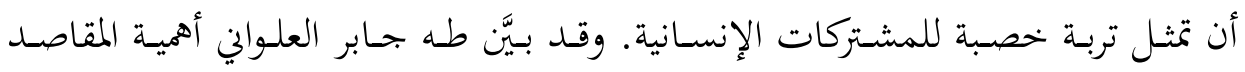

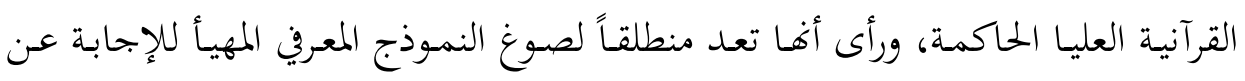

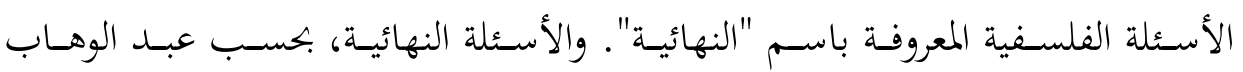

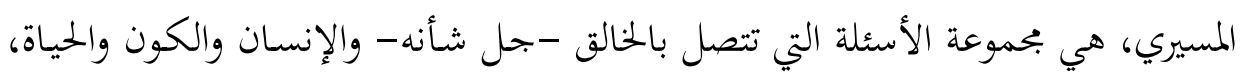

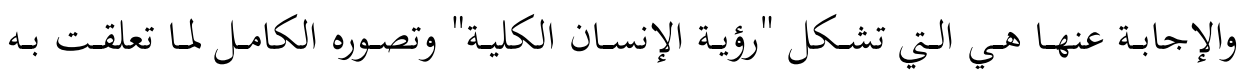

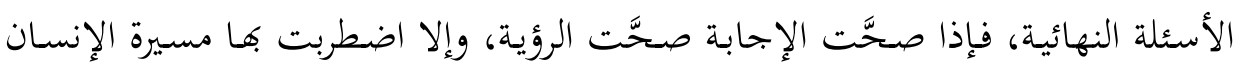
في الحياة. rی

بr أبو سليمان، عبد الحميد. مختصر كتاب الرؤية الكونية الحضـارية القرآنيـة، فيرجينيا: المعهد العالمي للفكر

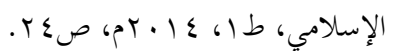

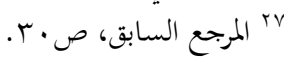
ه 
ويقول العلواني في بيـان أهمية مقاصـد القرآن الكريم المتعلقـة بتأسيس أرضية جامعة للمشترك الإنساني: "المقاصد العليا الحاكمة يمكن أن تمثل بجملتها أو ببعضها علئل على الأقل

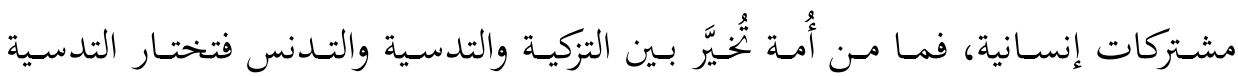

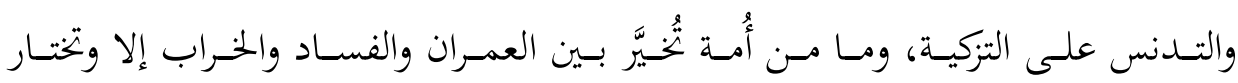

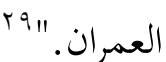

\section{ثانياً: جهود المعاصرين في بيان مقاصد القرآن الكريم في بناء الحضارة والعمران} مـن مقاصــ القـرآن الأساسـية التي تمثـل مركز السـاق مـن الشـجرة مقصـد (عمـارة

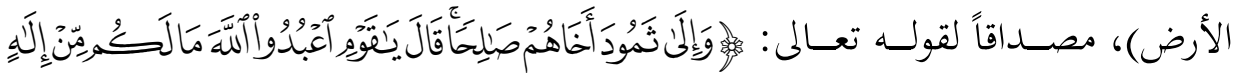

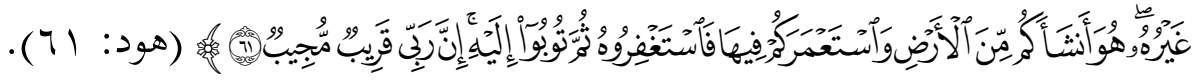
ولا يتحقق هـا الإعمار مـن دون فهم حقيقة الكون وغاية الإنسان فيه؛ فإعماره

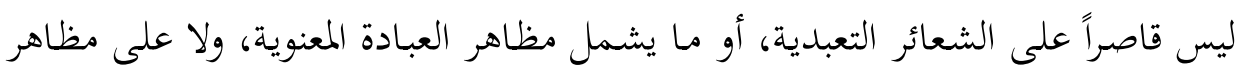

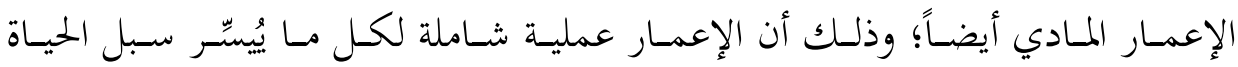

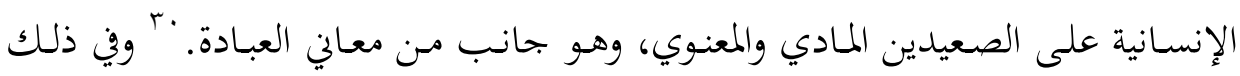

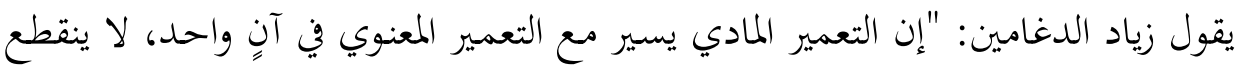

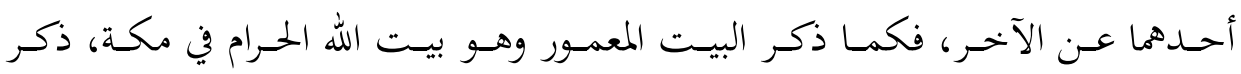

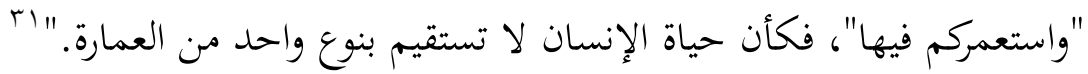

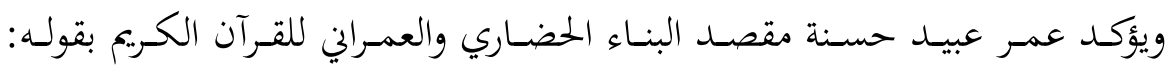

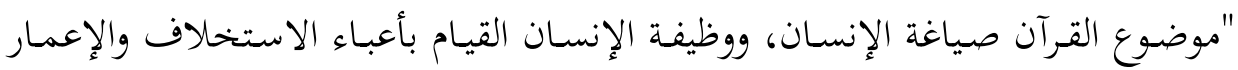

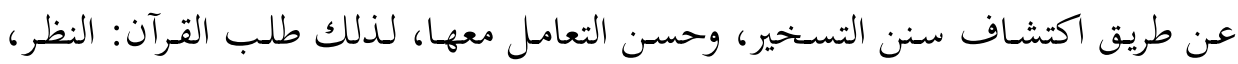

- المسيري، عبد الوهاب. موسوعة اليهود واليهودية والصهيونية، القاهرة: دار الشروق، 991 ام.

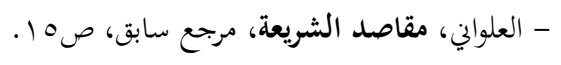

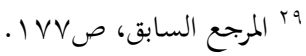

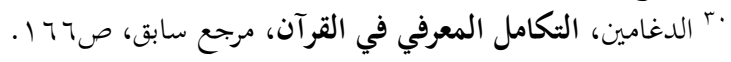

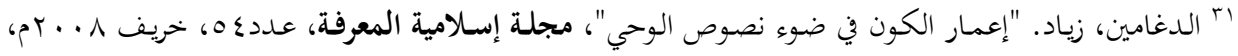




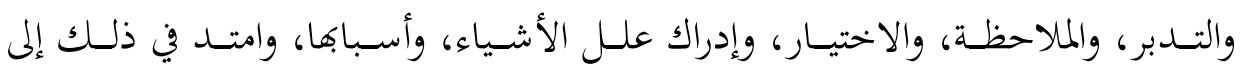

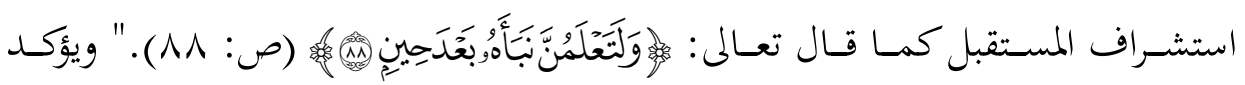

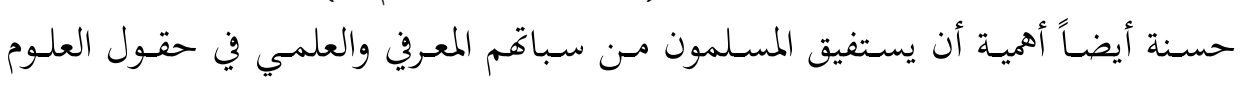

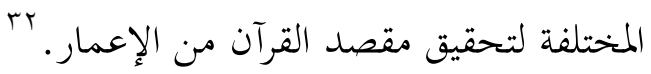

وفيما يأتي بعض مقاصد القرآن الكريع في بناء الحضارة والعمران عند المعاصرين:

\section{1 ـ مقاصد القرآن الكريم في بناء الحضارة والعمران عند محمد رشيد رضا:}

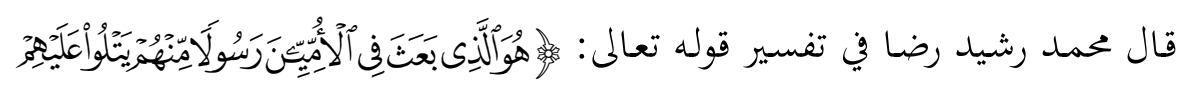

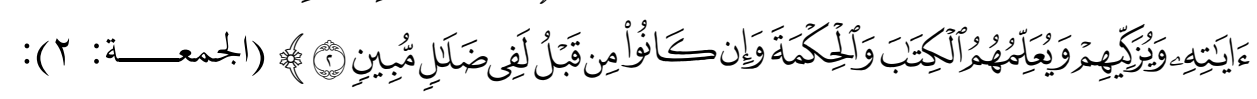

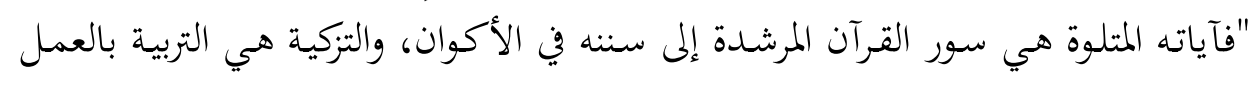

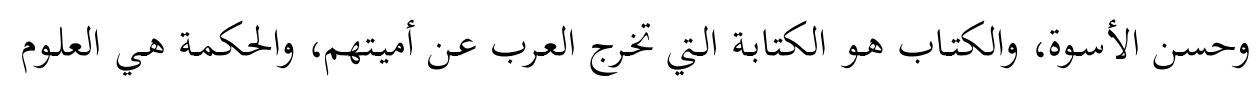

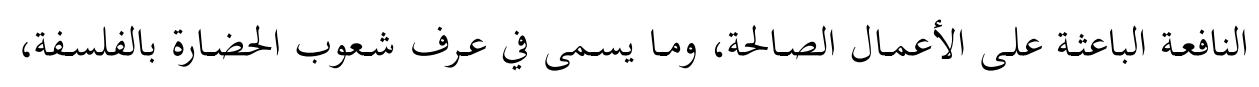

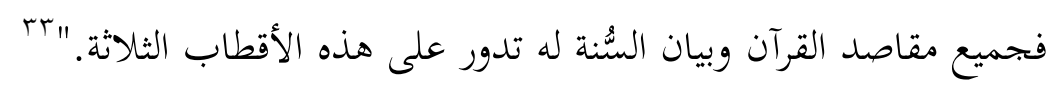

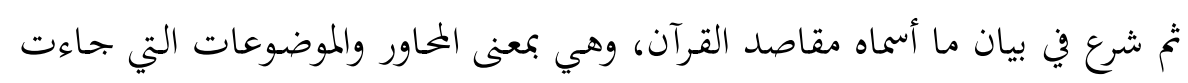

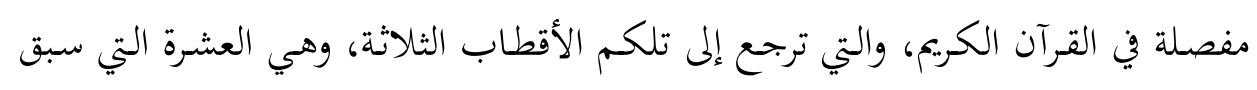
ذكرها.

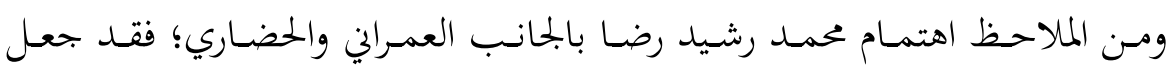

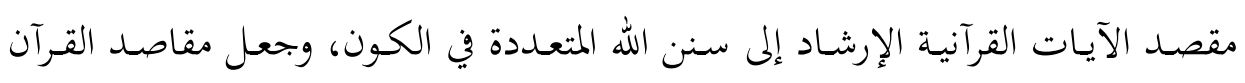
الكريم العلم الذي يبني هذه الحضارة، وبيَّن أن الحكمة هي تعلُّم العلوم النافعة التي تُُقِقِق

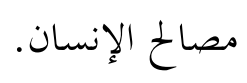

r. مقاصد القرآن الكريم في بنـاء الحضـارة والعمران عند محمد الطاهر بن عاشور:

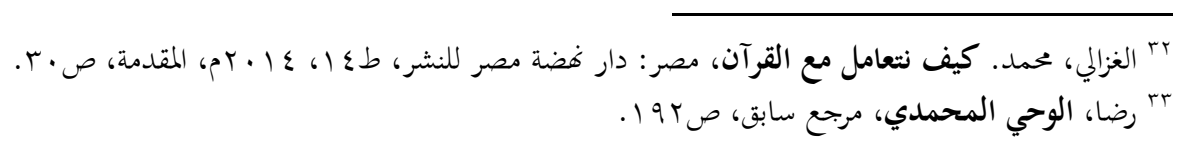




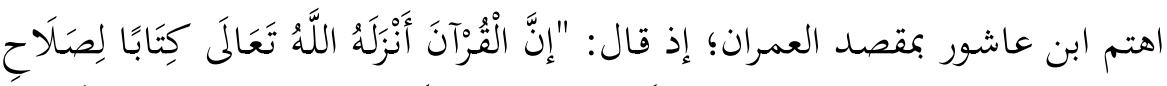

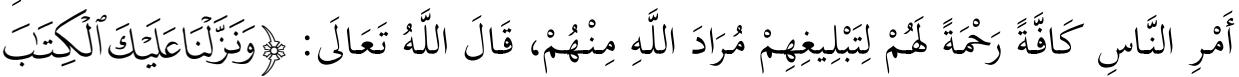

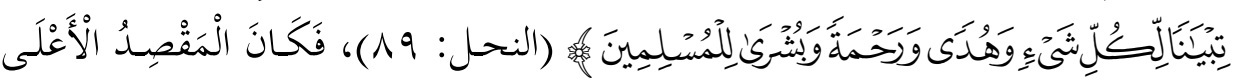

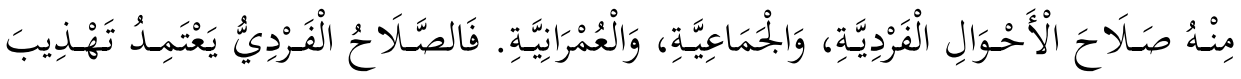

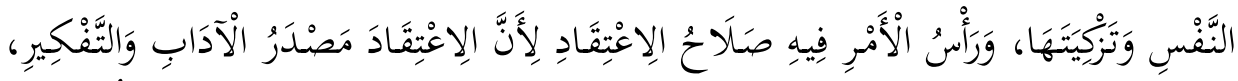

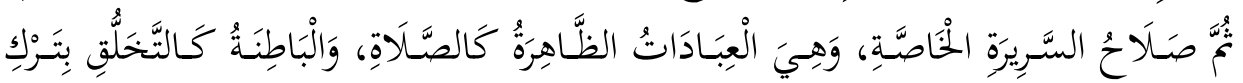

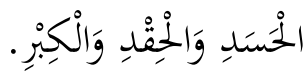

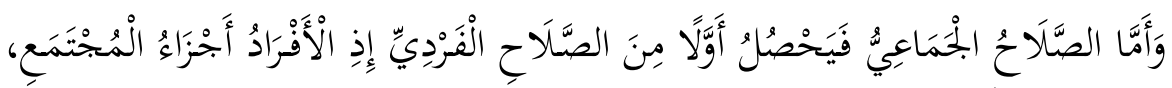

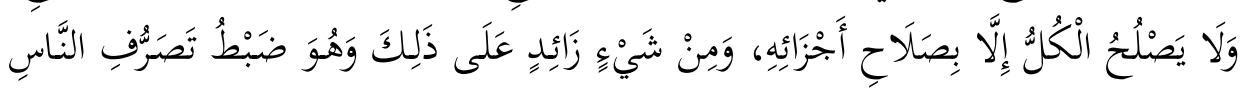

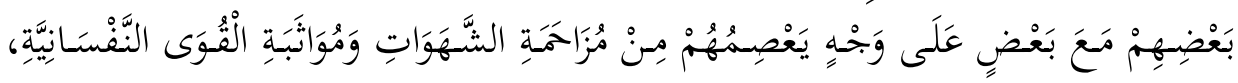

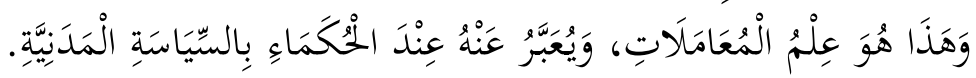

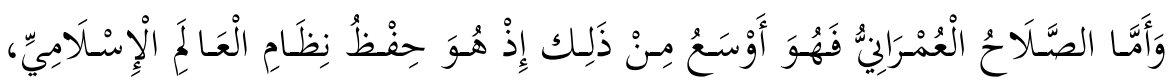

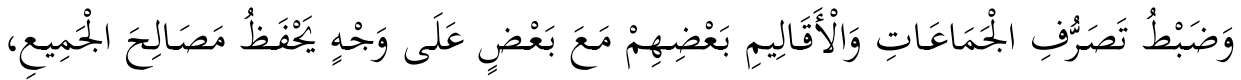

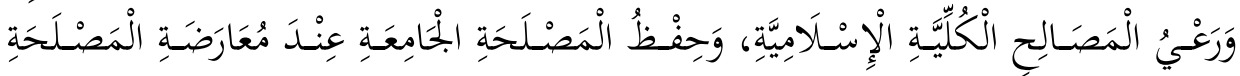

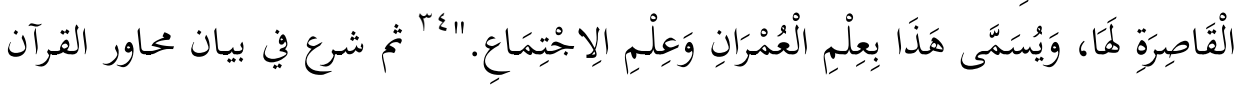

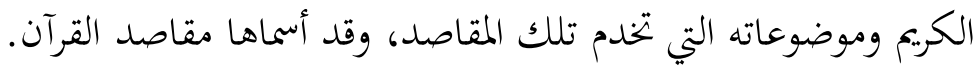

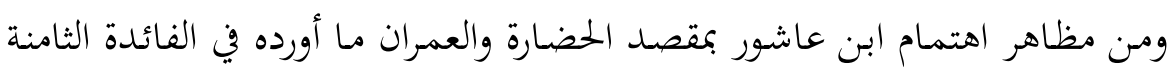

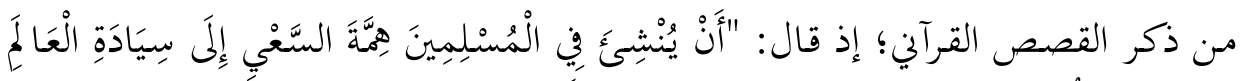

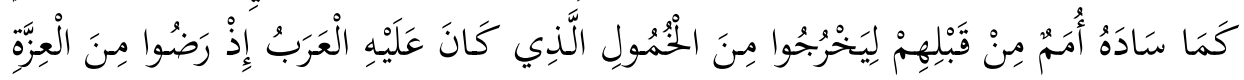

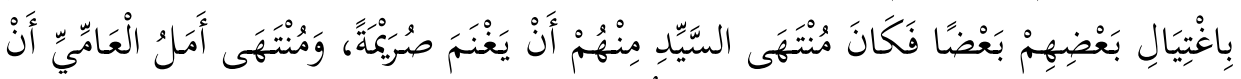

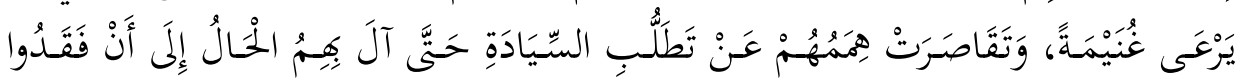

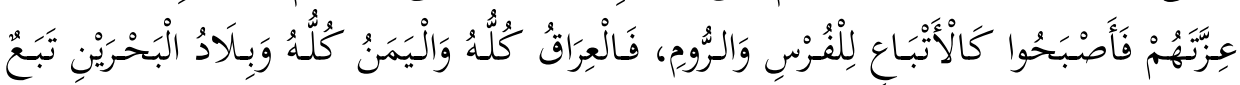

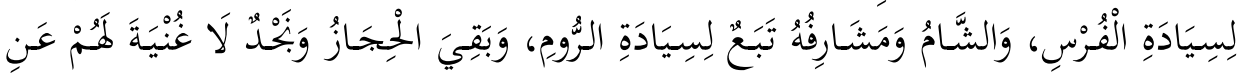

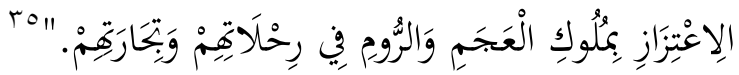

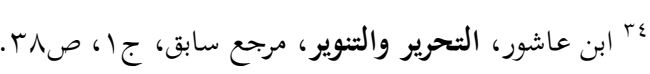

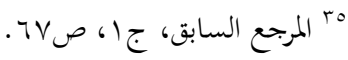




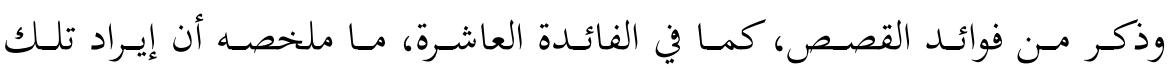

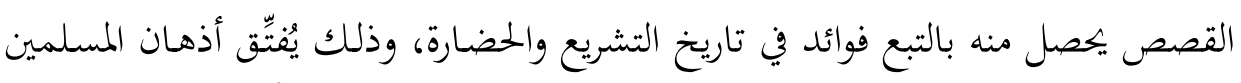

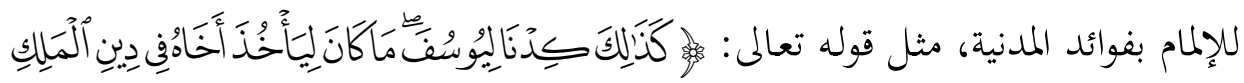

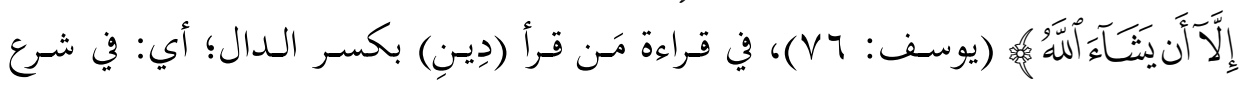

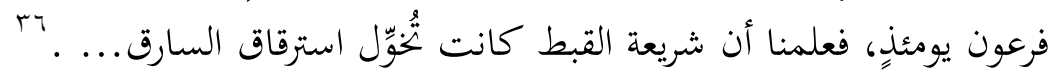

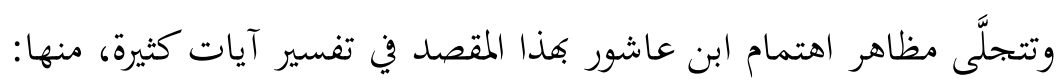

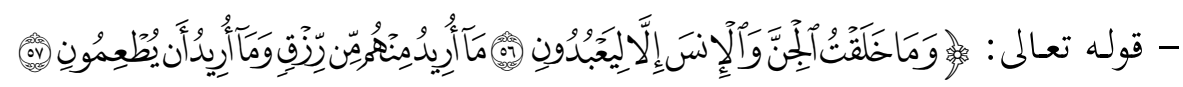

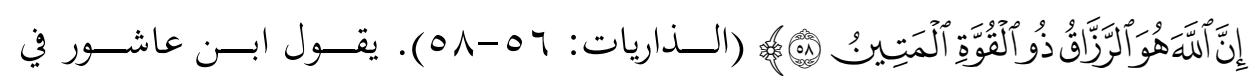

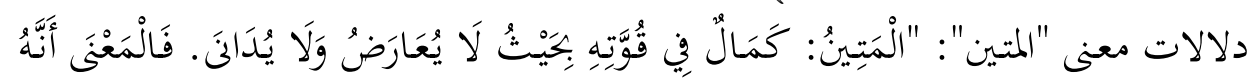

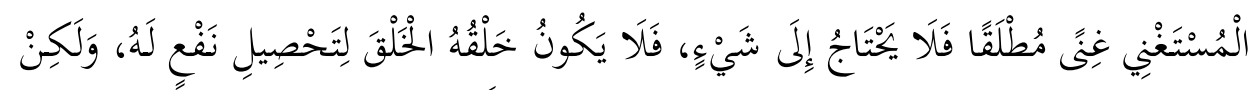

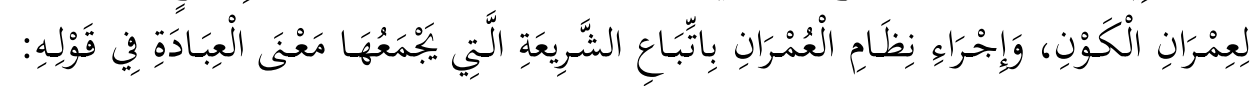

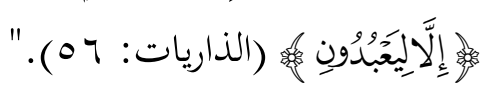

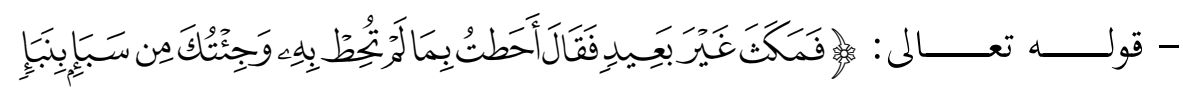

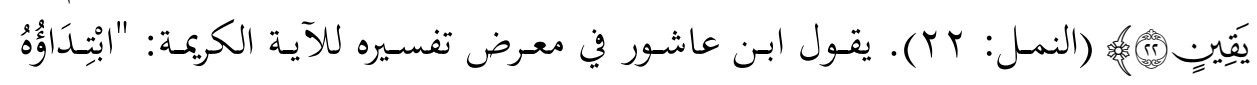

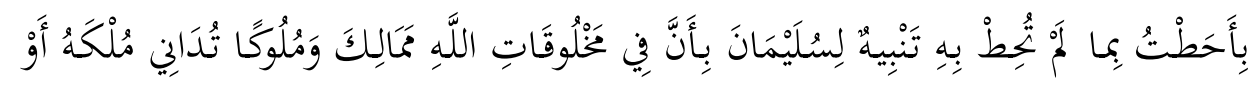

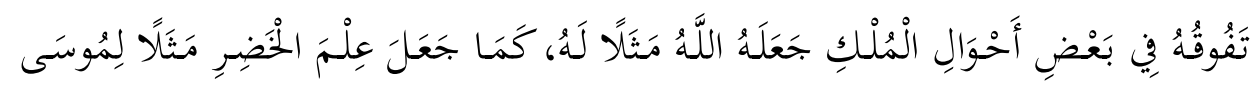

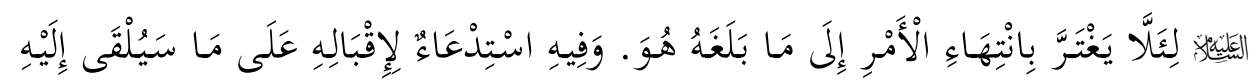

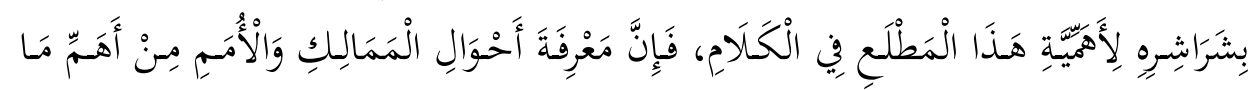

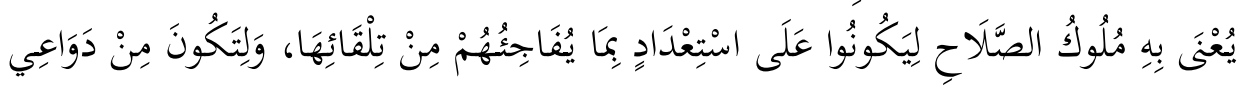

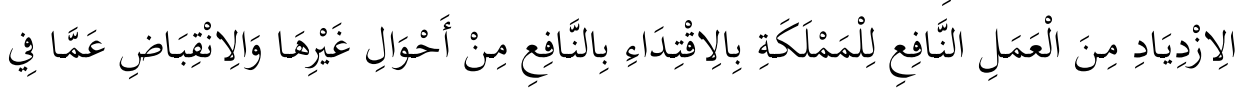

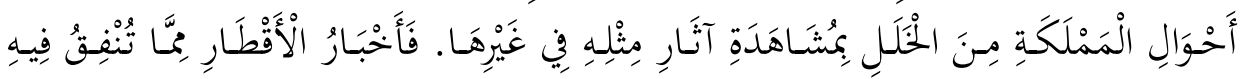

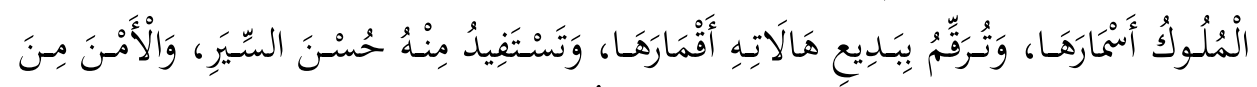

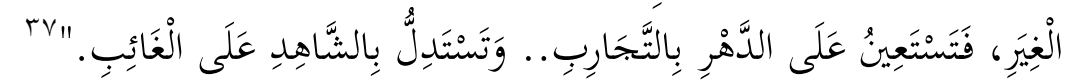

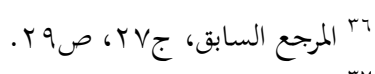

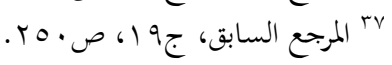




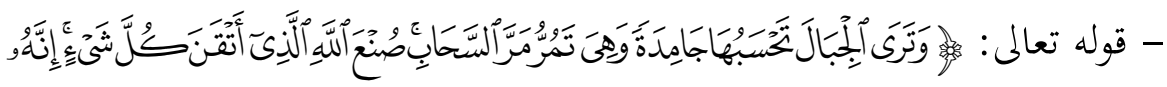

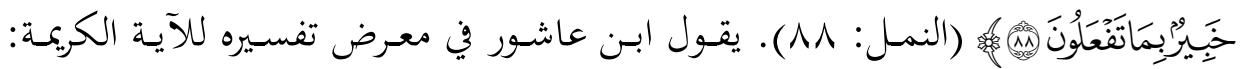

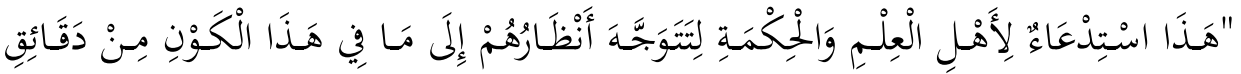

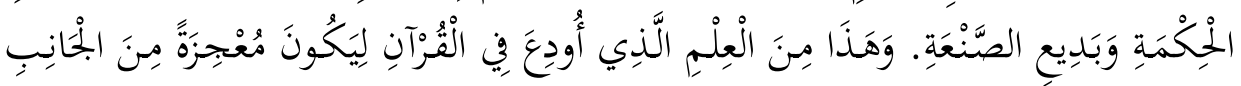

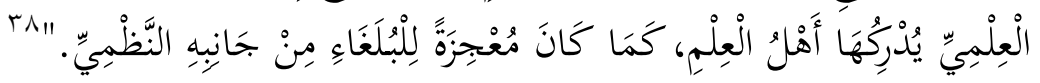

\section{r. مقاصد القرآن الكريم في بناء الحضارة والعمران عند علال الفاسي:}

يرى علال الفاسي أن المقصد العام للشريعة الإسلامية هو عمارة الأرض، وحفظ

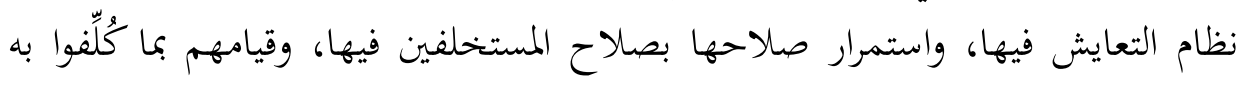

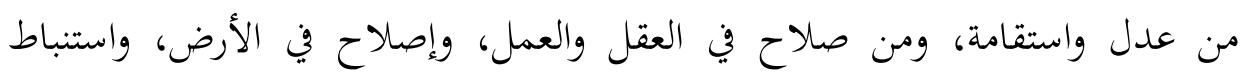

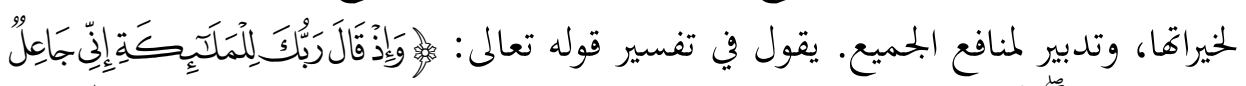

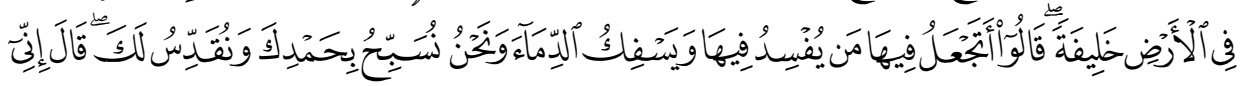

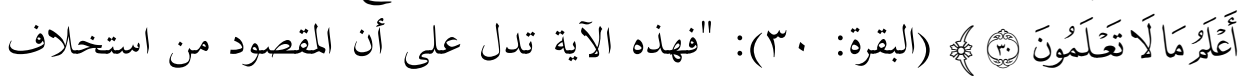

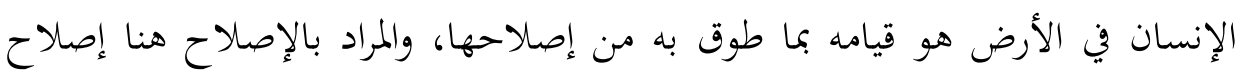

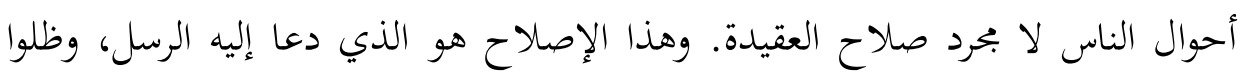

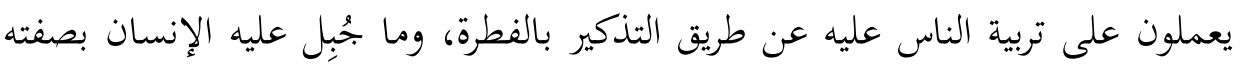

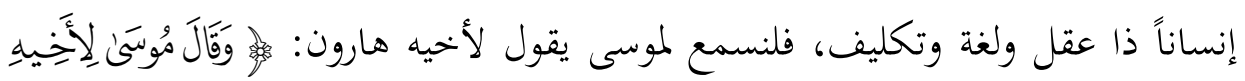

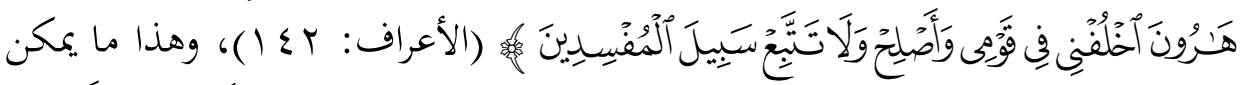

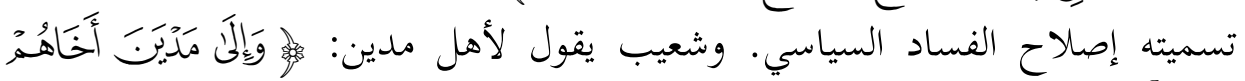

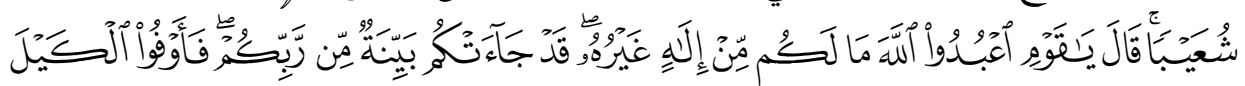

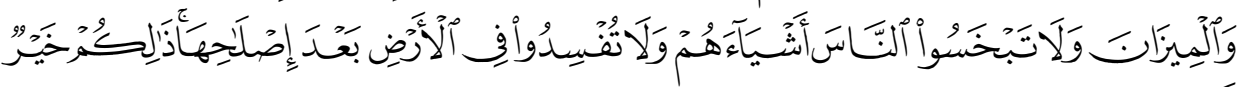

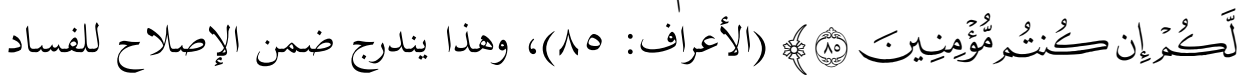

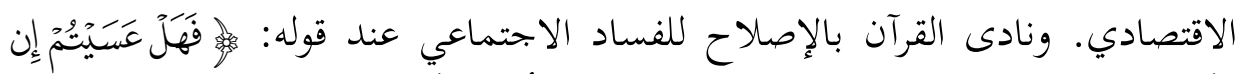

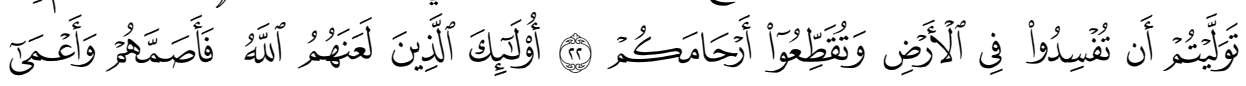

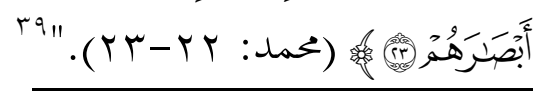

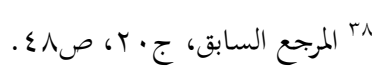

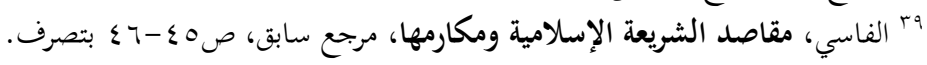




\section{ع. مقاصد القرآن الكريم في بناء الحضارة والعمران عند محمد الغزالي:}

حـرص الشـــخ الغـزالي -رحمـه الله- على بحليـة مقصـد القـرآن في البنـاء الحضــاري

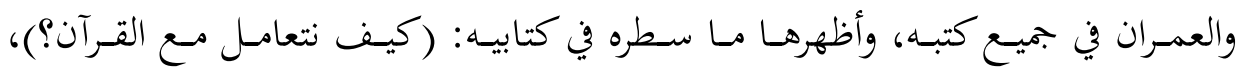

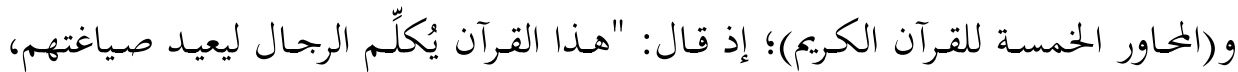

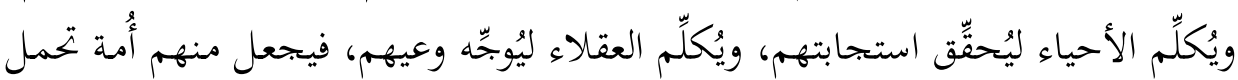

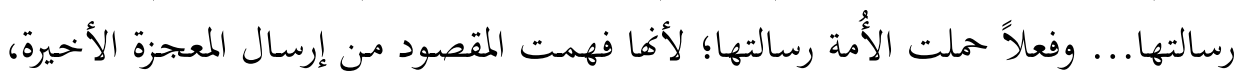

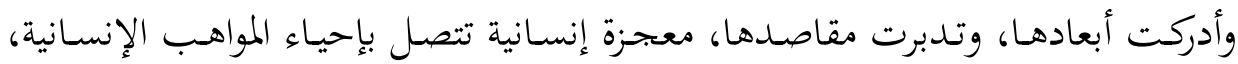

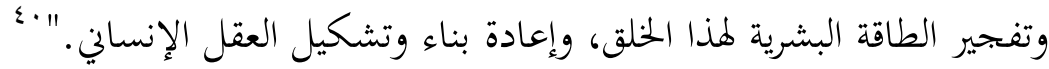
ويظهر اهتمام الغزالي بهذا المقصد من زوايا عدَّة، منها:

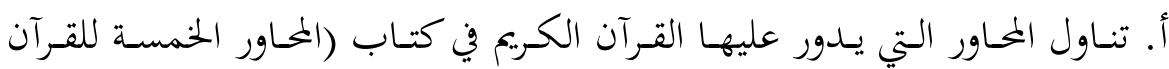
الكريم)، واعتبار هذه المحاور تتناسق بصورة تكاملية لتبني أُمة حضارية. "فالمحاور التي يقوم

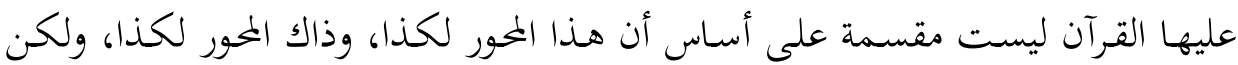

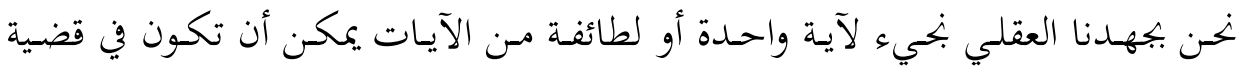
واحدة، فنرى أن هذه القضية الواحدة تماسكت الآيات فيها على عدَّة محاور من الكادلام

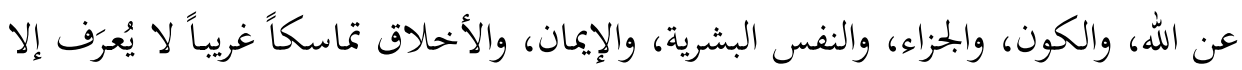

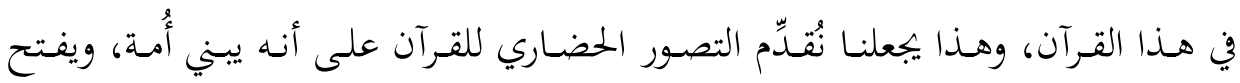

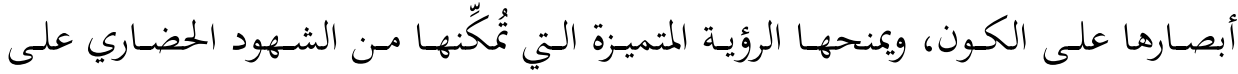

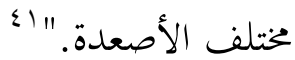

ب. الدعوة إلى إدراك السـن الآلهية في الأنفس والآفـاق (مثل: سُسنَّة التدرج، وسُسنَّة

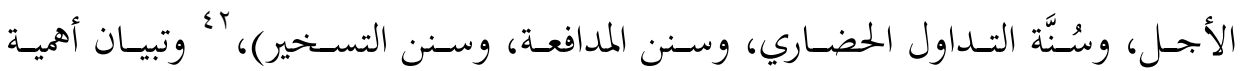

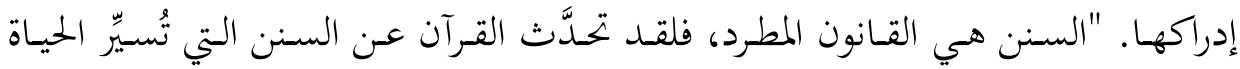

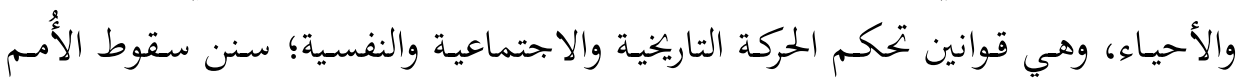




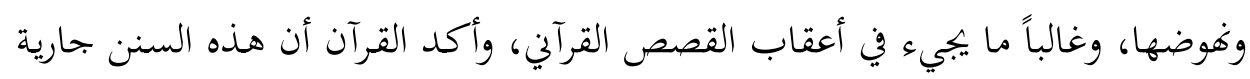

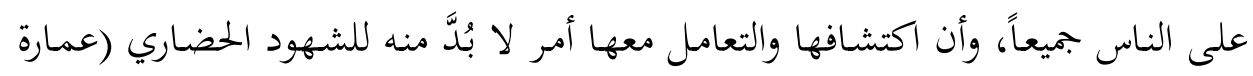

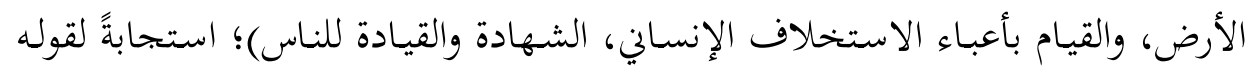

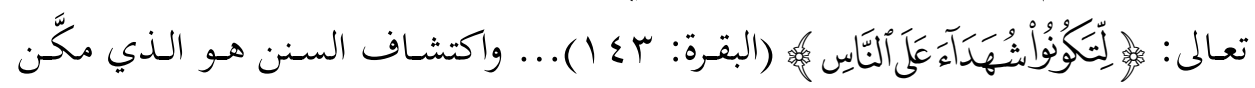

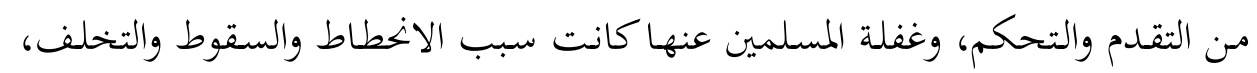

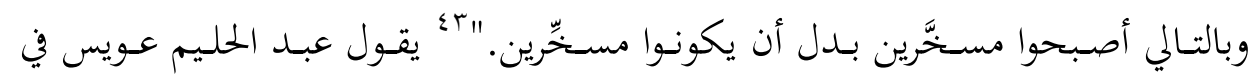

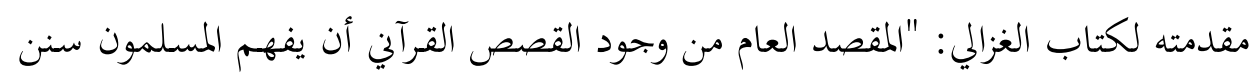

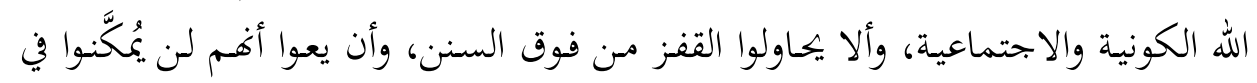

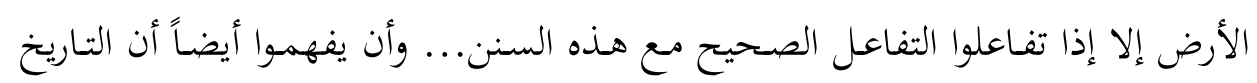

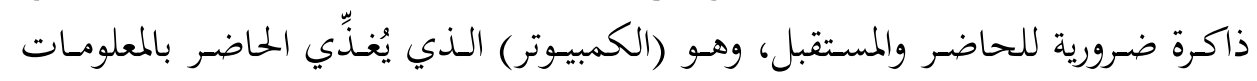

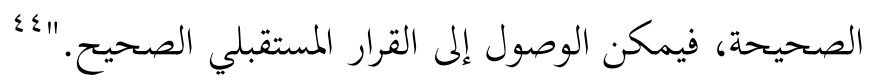

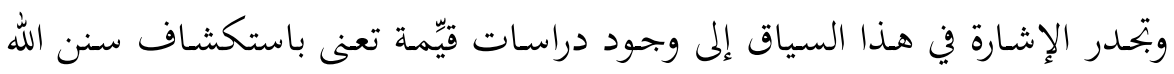

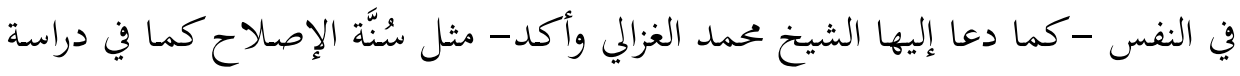

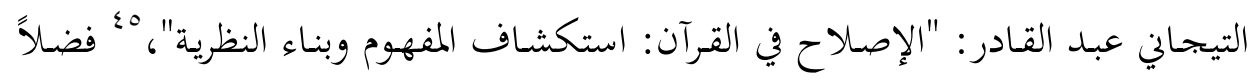

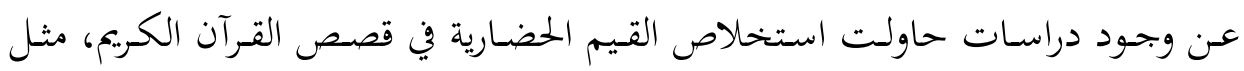

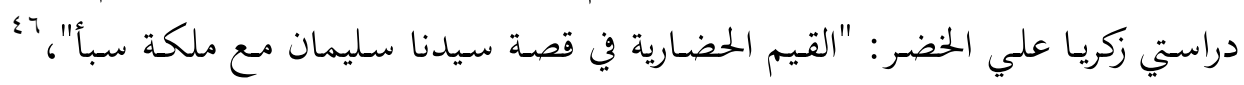

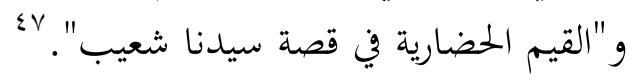

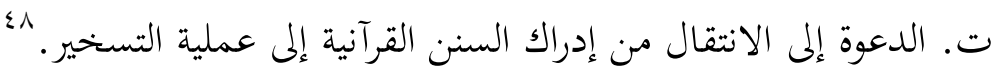

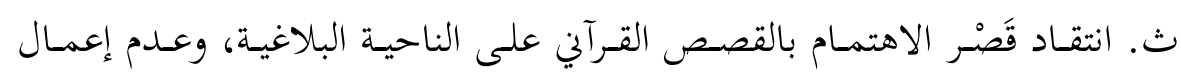

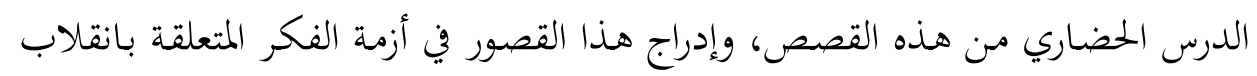
الوسائل إلى غايات، والغفلة عن غايات القرآن الكريم.

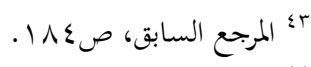

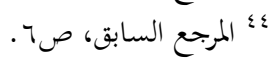

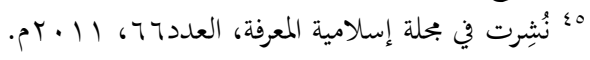

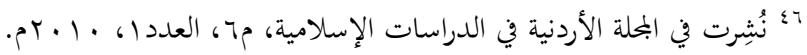

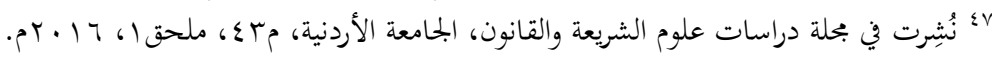

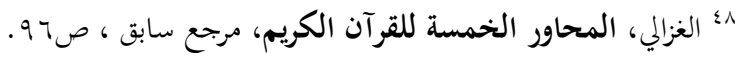




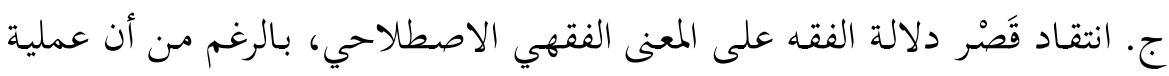

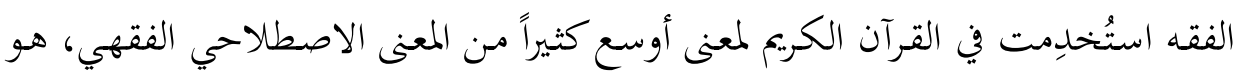
الفقه الخضاري.

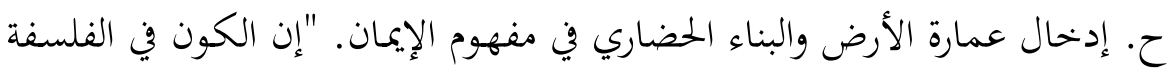

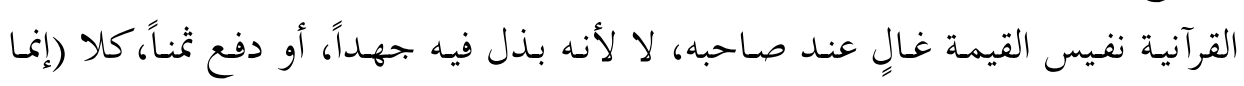

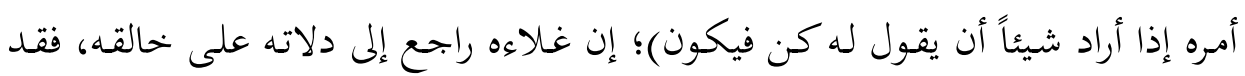

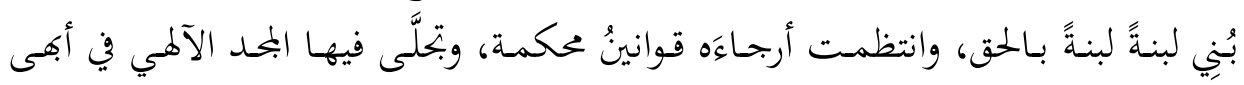

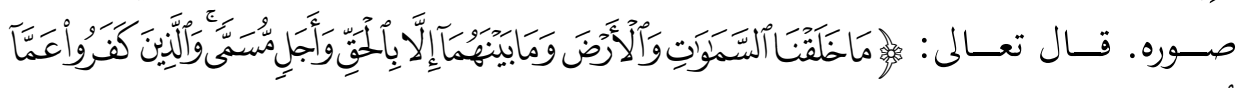

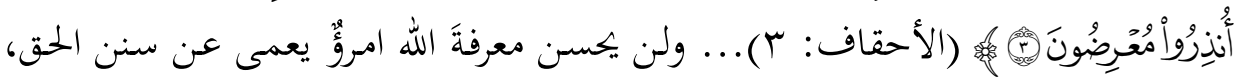

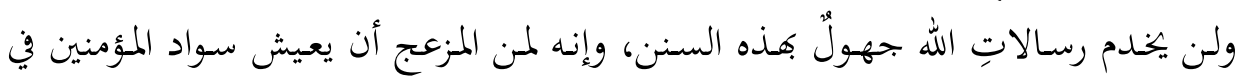

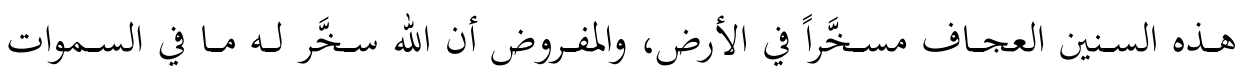

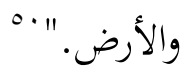

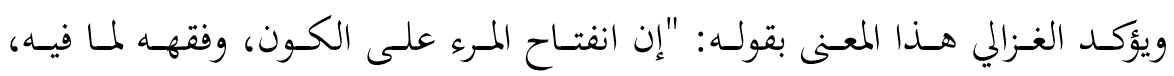

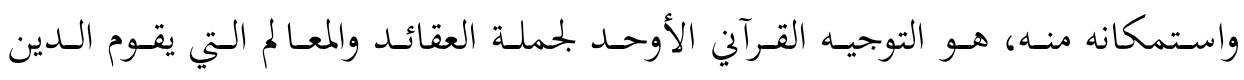

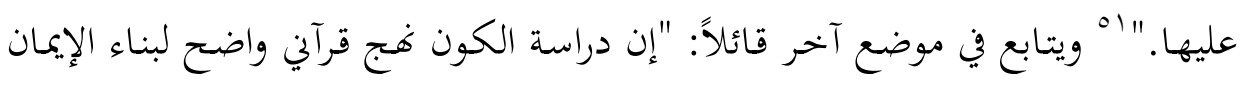

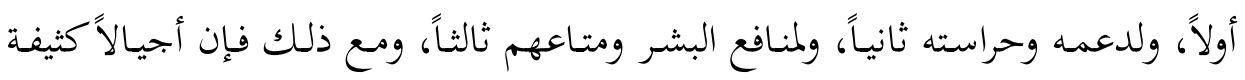

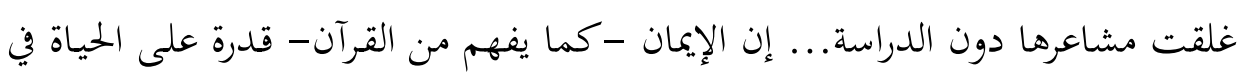

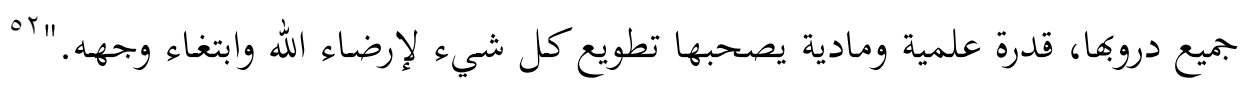

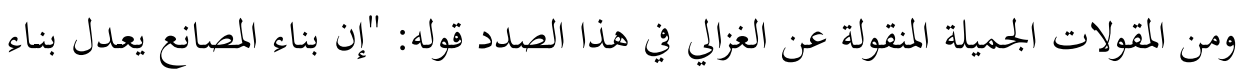

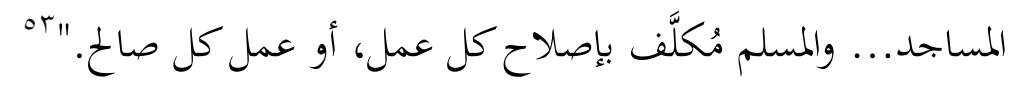

$$
\begin{aligned}
& \text { 9 المرجع السابق، ص9 • } 1 .
\end{aligned}
$$

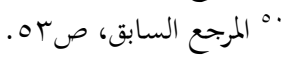

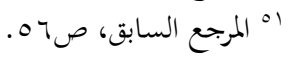

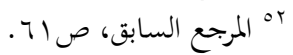

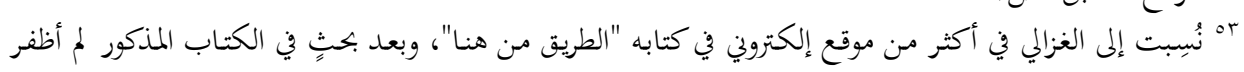




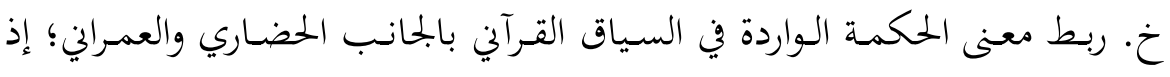

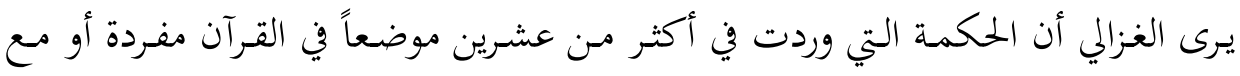

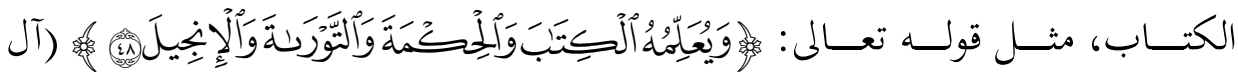

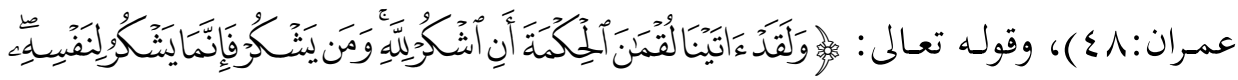

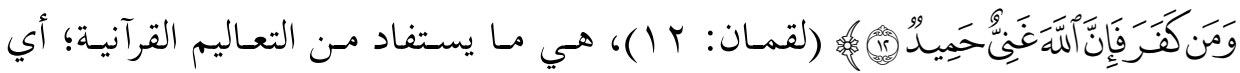

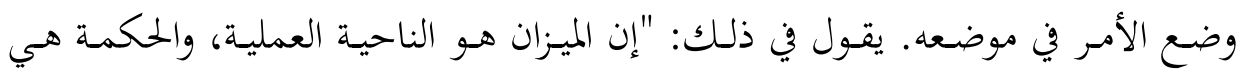
الناحية النظرية في ذلك، فمجموعة الآيات التي وردت فيها الحكمة والميزان تعطينا منهجاً

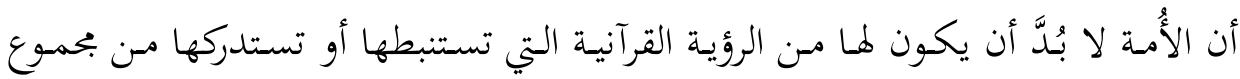

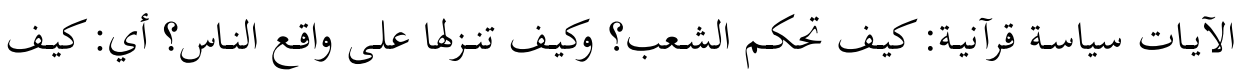

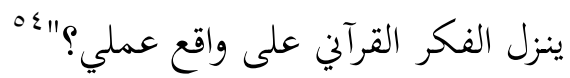

ويمكن تلخيص ما قاله الغزالي في معنى الحكمة بلفظ آخر، هو تكوين الرؤية، وهذه الرؤية هي ثمرة وخلاصة لإعمال المقاصد التي تحمل الجحانبين: الفكري والنظري.

\section{ه. مقاصد القرآن الكريم في بناء الحضارة والعمران عند طه جابر العلواني:}

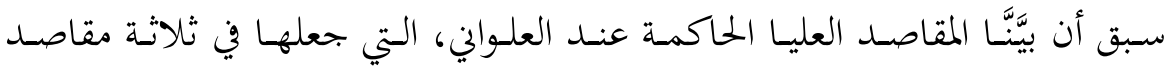
(التوحيد، والتزكية، والعمران)، والتي خصَّ الجانب العمراني والبناء الحضاري منها لئها ليكون

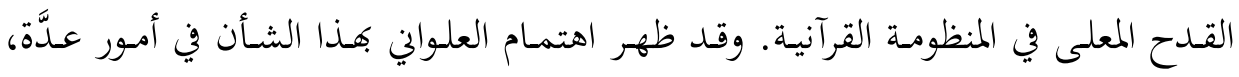

أ. إدخال الاستخلاف والإعمار في مفهوم العبادة. "فالعبادة التي جعلها الله غاية

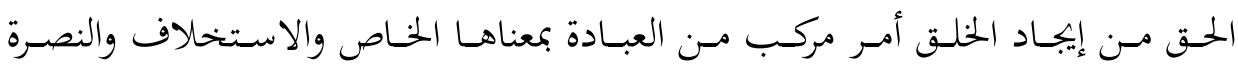

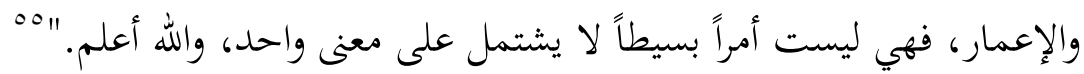

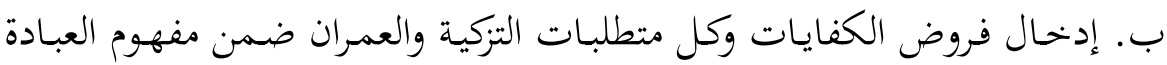




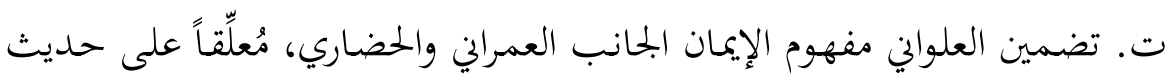

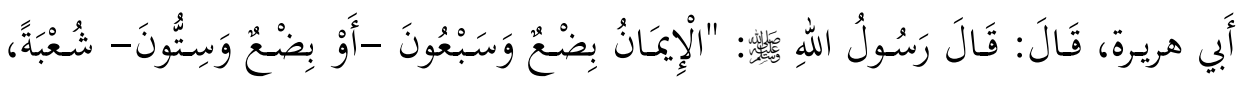

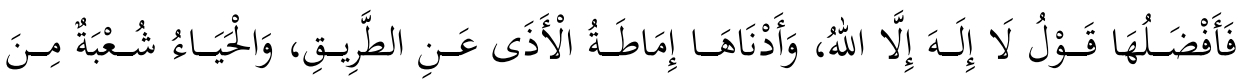

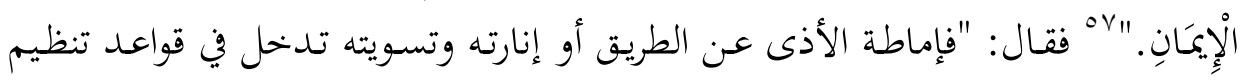

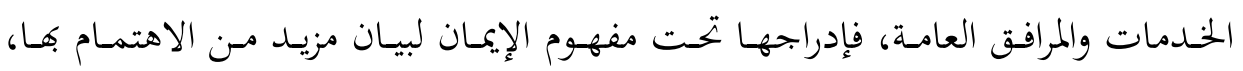

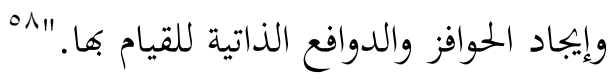

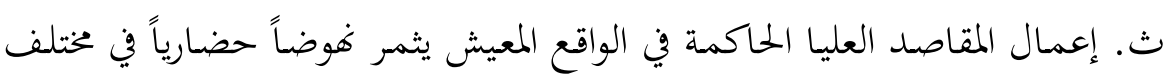

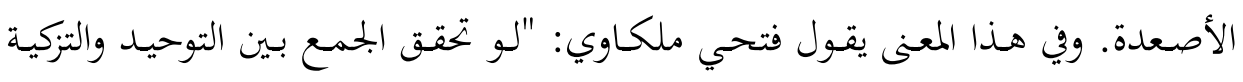

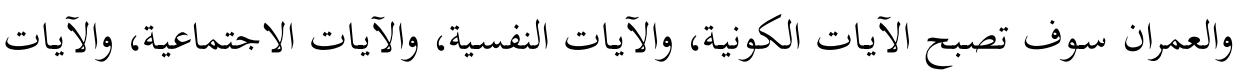

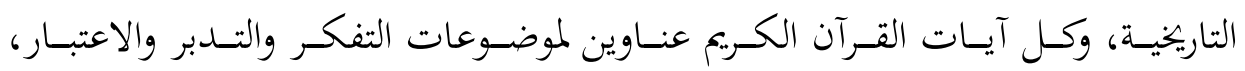

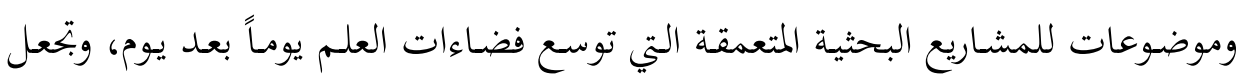

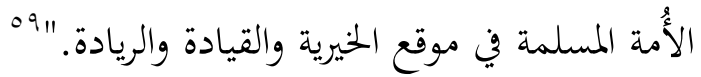

\section{7. مقاصد القرآن الكريم في بناء الحضارة والعمران عند جاسر عودة:}

دعا جاسر عودة في كثير من كتاباته المتخصصة في مقاصد الشريعة إلى إعادة النظر

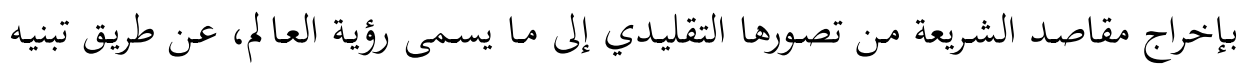

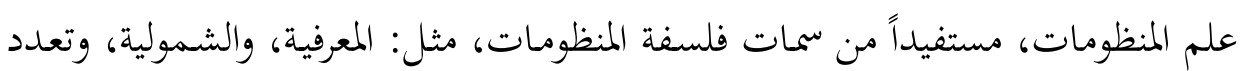

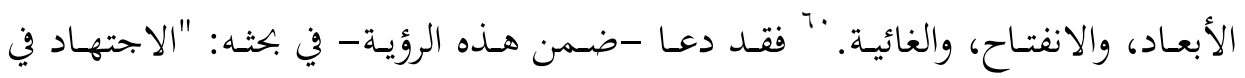

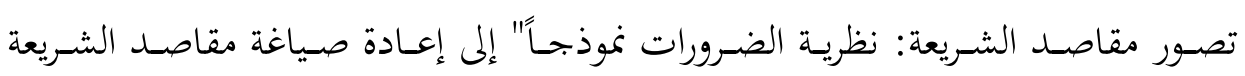
لاه ابن الحجاج، مسلم. صحيح مسلم، تحقيق: محمد فؤاد عبد الباقي، بيروت: دار إحياء التراث، كتاب: الإيمان،

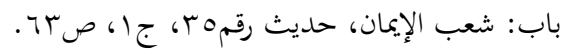

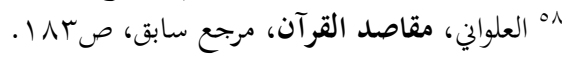

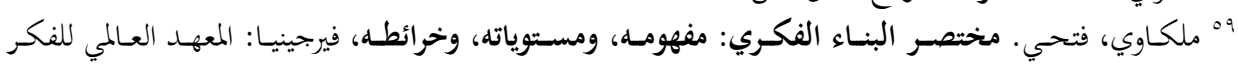

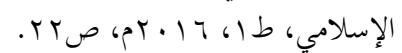

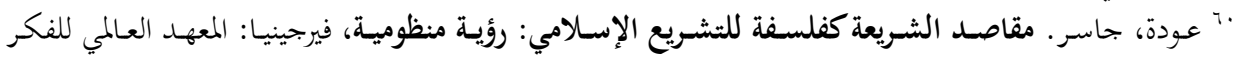

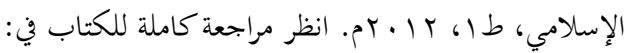

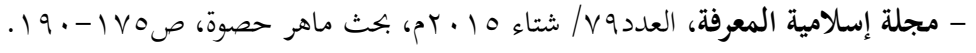


المتعلقـة بالضـروريات الخمـس ضـمن رؤية العـالم وحاجاته الحضـارية بالانتقـال مـن حفظ النسل في إطاره التقليدي إلى مفهوم بناء الأسرة، ومن حفظ المال إلى التنمية الاقتصادية، ومن حفظ النسل والعرض إلى حفظ حقوق الإنسان، ومن حفظ العقل إلى نماء الملكات العقلية والفكرية، ومن حفظ الدين إلى كفالة الحريات الدينية.

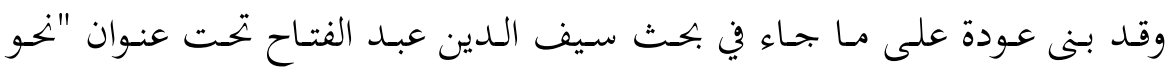

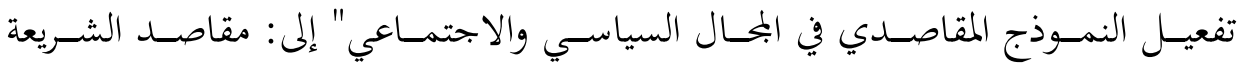

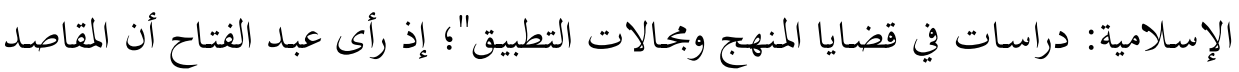
الكلية ليست إلا صياغة لمفهوم متكامل للتنمية من منظور حضاري. فقد اقتنص عودة

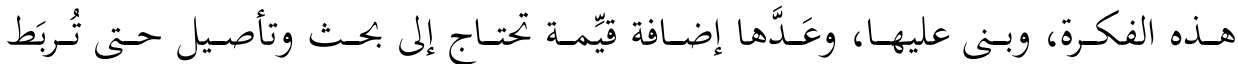

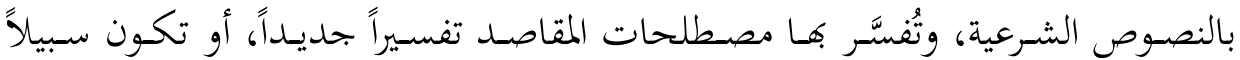
لتقديم مصطلحات مقاصدية جديدة أقرب إلى رؤية العالم فيما يصلح للناس. بات والإضافة التي اقترحها الباحث في هذا السياق تتمثل في أن تقارير الأمم المتحدة -

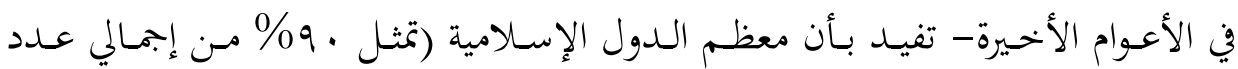
المسلمين) تُصنَّف ضمن مستوى أقل من المتوسط بحسب مقياس التنمية البشرية (يمثل مئل

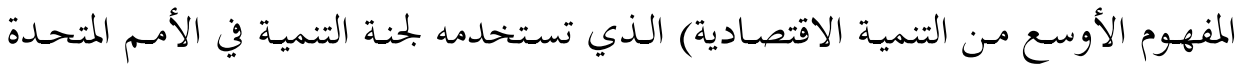

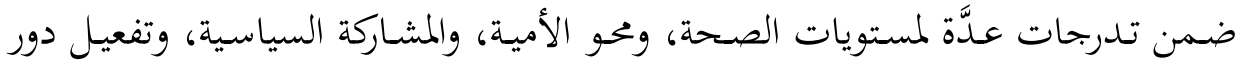

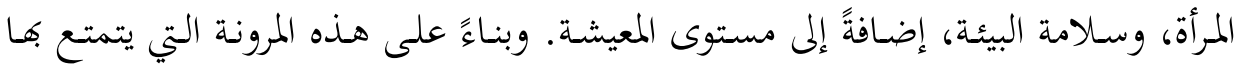
مصطلح المقاصد، فإنه يمكن صياغة مقصد للتنمية البشرية يكون له تميزه بإضافة مقاييس

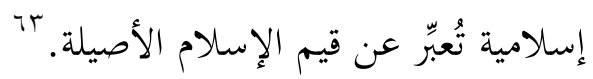

وهذه الإضافة التي اقترحها عودة أرى أهفا تمثل معياراً واقعياً لمقصد العمران (ضمن إلهن

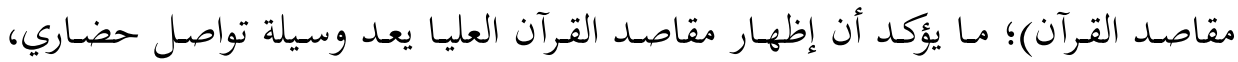

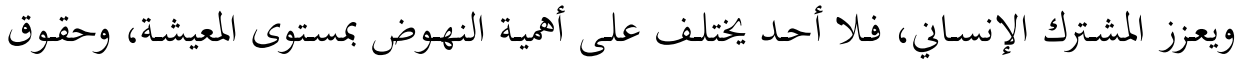
المرأة، والتعليم، والصحة، وسلامة البيئة، إلى غير ذلك مئا جـاء في معايير قياس التنمية

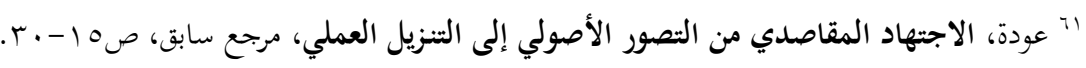
rا" المرجع السابق، صعُ الاجتهاد العاصدي rا" عودة، الاجتهاد المقاصدي من التصور الأصولي إلى التنزيل العملي، مرجع سابق،صهـ. 
البشـرية، مـن دون إغفـال أتثر المسـاهمة الفكريـة في تعزيـز تلـك المعـايير وتقويمها بـالحوار والإقناع من منطلق الثوابت والقيم الإسلامية، مع احترام الجانب الثقافي لكل أُمة.

\section{ثالثاً: مقصد تقويم الفكر عند المعاصرين}

يعـد تقـويم الفكـر أحسد تفرعـات مقاصــ القـرآن في العمـران. وفي نظـرة متفحصـة

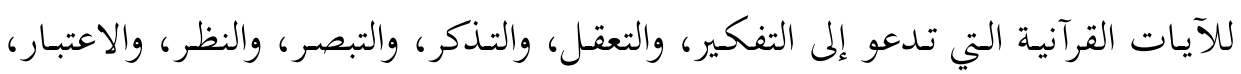

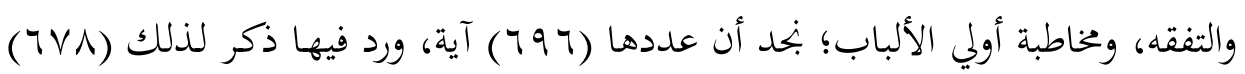

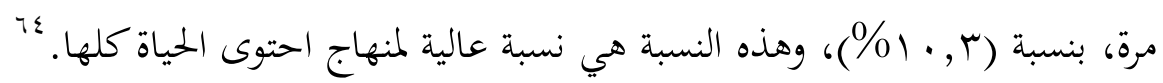

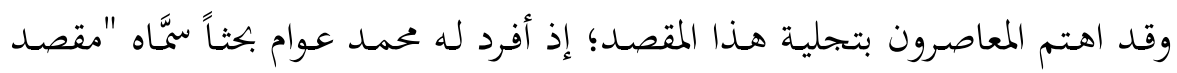

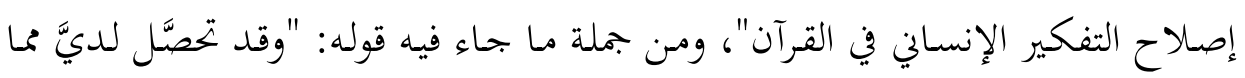

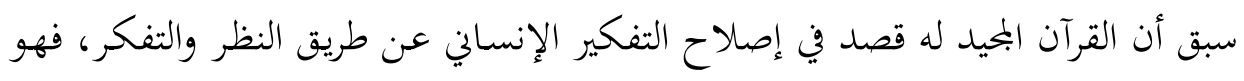

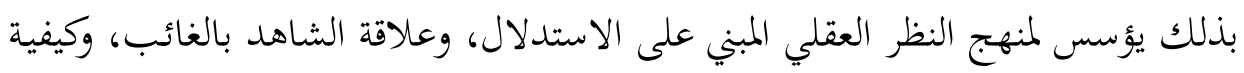

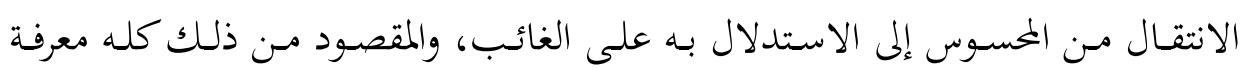

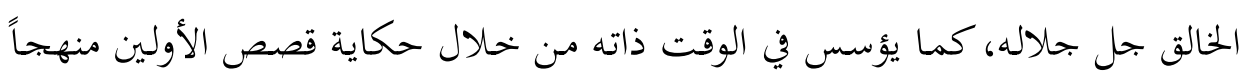

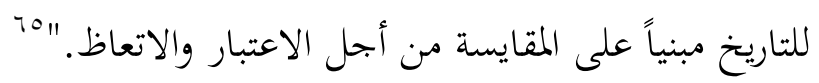

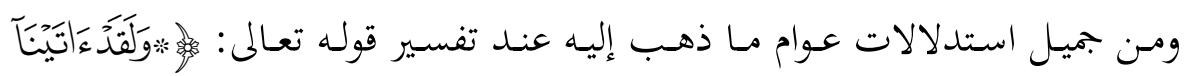

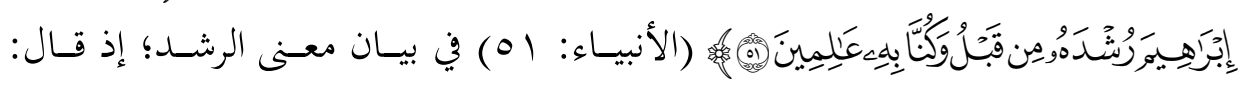

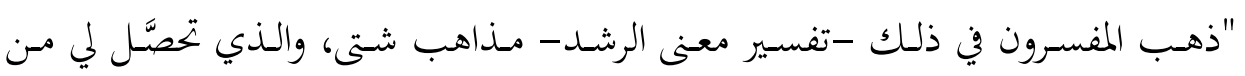

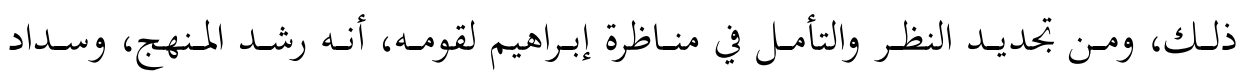

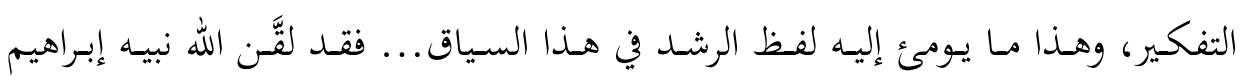

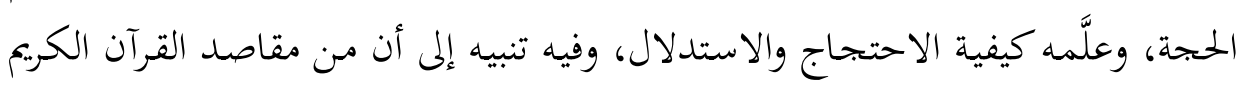

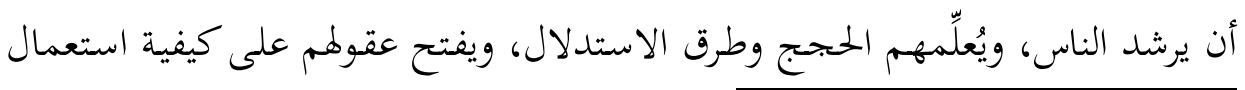

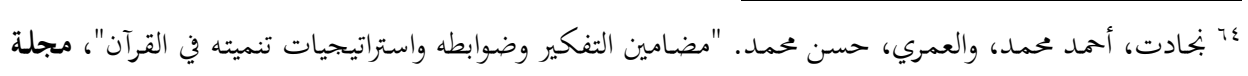

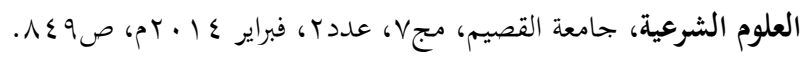

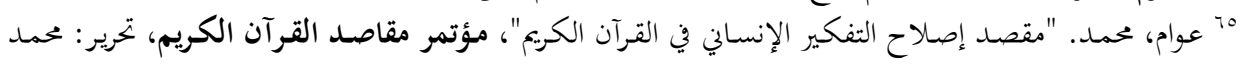

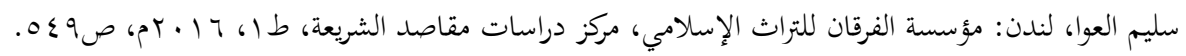


الحجـج والبراهين، ثم هـم -بالعقول التي ركزت فيهم، وبفطرهم السليمة- سيهتدون إلى إلى

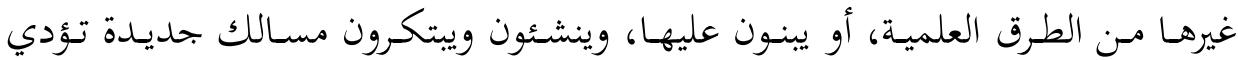

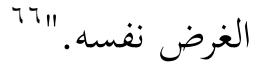

\section{1 ـ مقصد تقويم الفكر عند محمد رشيد رضا:}

تناول محمد رشيد رضا هذا المقصد عند تفصيله المقصد الثالث مـن مقاصد القرآن بقوله: "إكمال نفس الإنسان من الأفراد والجماعات والأقوام بجعل الإسلام دين الفطرة

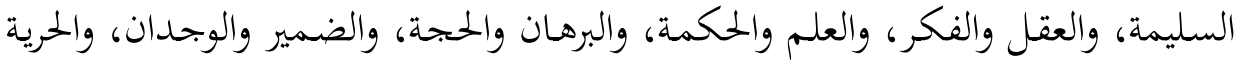

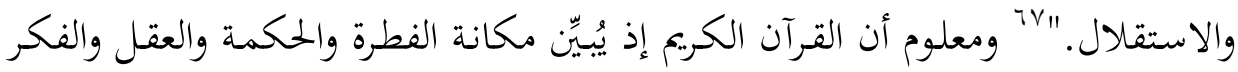
والعلم والبرهان... فإنما قصده في ذلك تثبيت هذه المكانة، والحث على رعايتها، وتحصيل مفعولها.

وقد نقل محمد رشيد رضاعن شيخه الإمام محمد عبده المقصود بالحكمة، فقال:

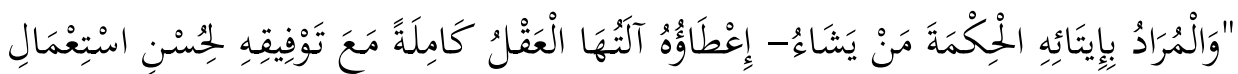

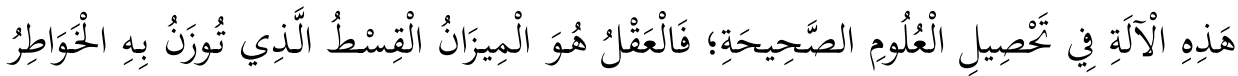

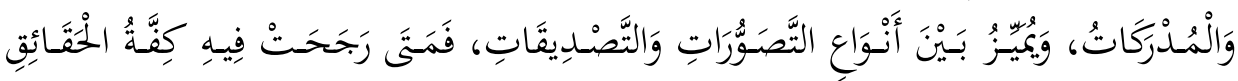

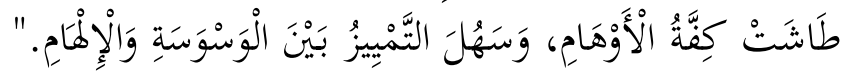

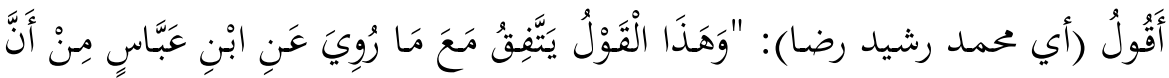

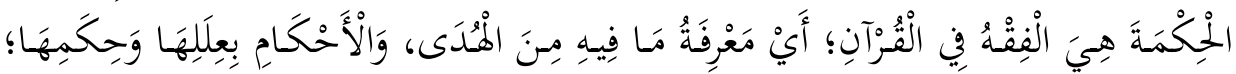

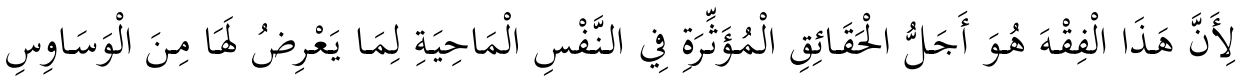

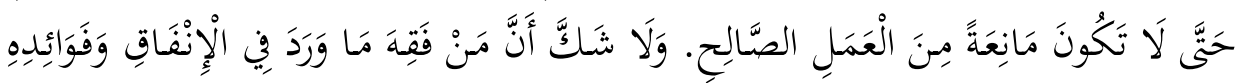

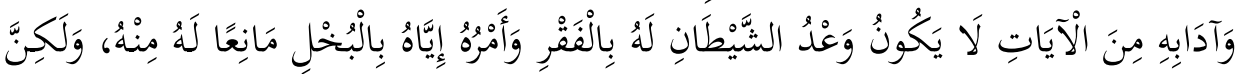

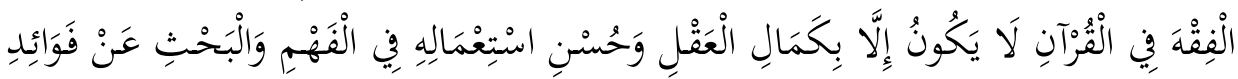

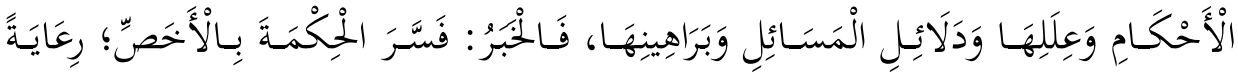

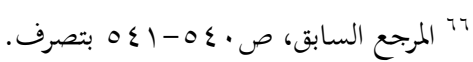

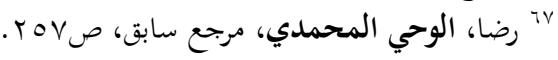




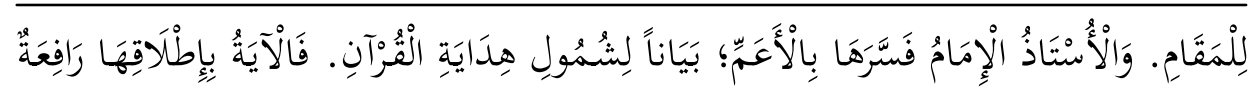

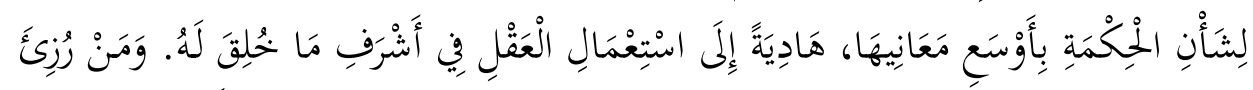

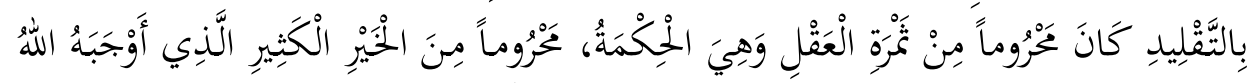

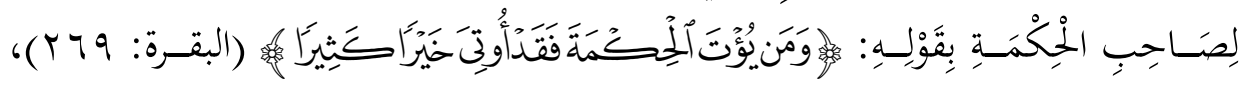

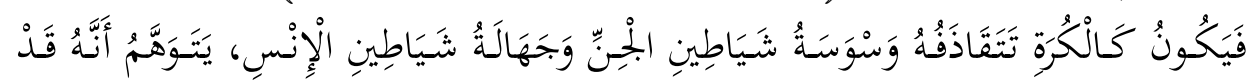

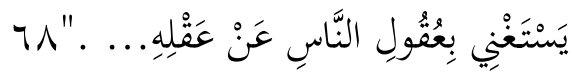

\section{r. I. مقصد تقويم الفكر عند ابن عاشور:}

يظهر اهتمام ابن عاشور بهذا المقصد جلياً في كثير مما سطره؛ إذ:

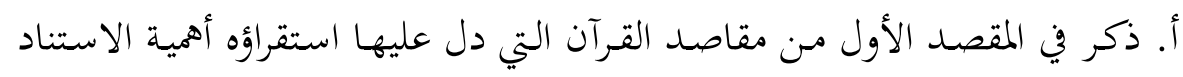

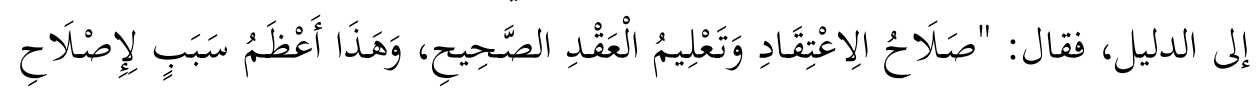

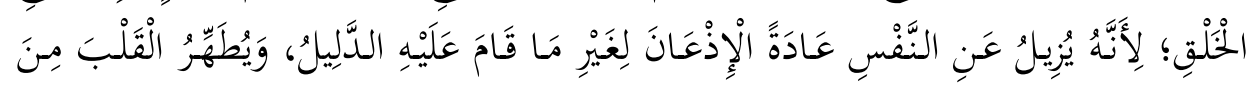

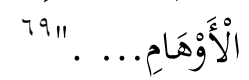

ب. ذكر في المقصد السادس ما يؤكد أن من مقاصد القرآن الأساسية تقويم الفكر:

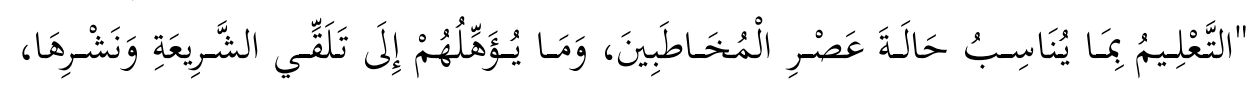

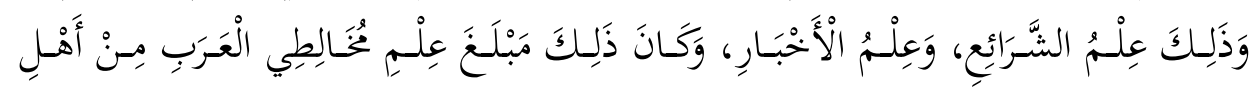

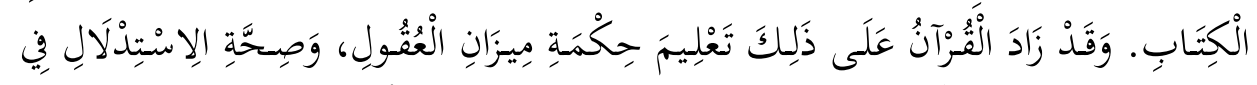

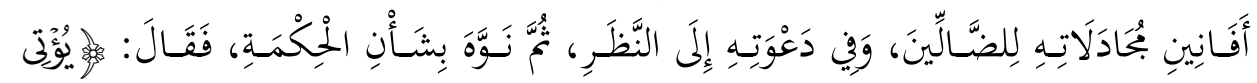

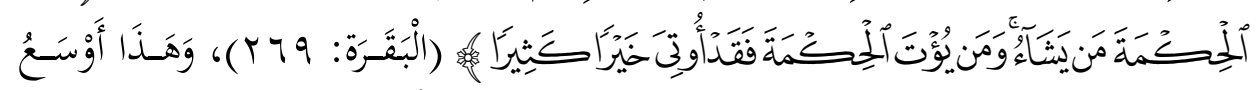

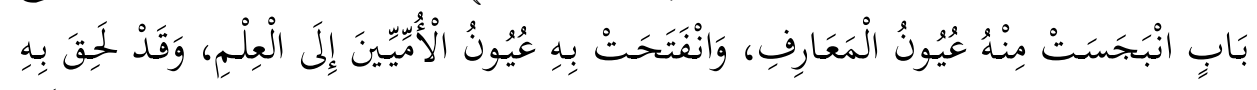

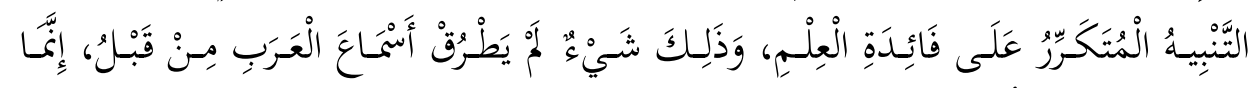

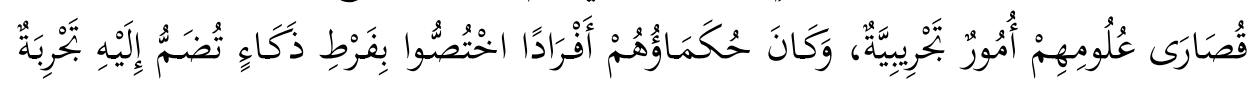

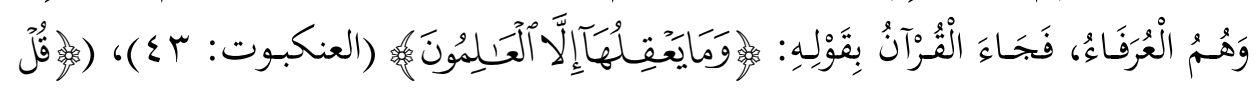

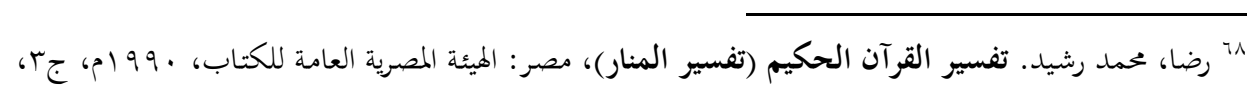
صغ بـ. 9י1 ابن عاشور، التحرير والنتوير، مرجع سابق، جا، ص. ؛. 


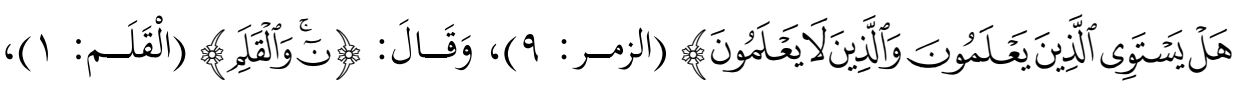

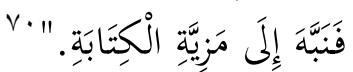

ت. ذكر في مقدمته ثمانية مقاصد دل عليها استقراؤه. وعند تفسيره الآيـة السابعة من سورة آل عمران استدرك ليضيف مقصدينِ بقوله: "آعلى أَنَّ مِنْ مَقَاصِدِ الْقُرْآنِ أَمْرَيْنِ

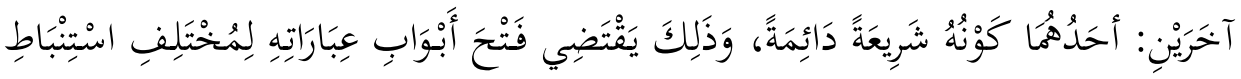

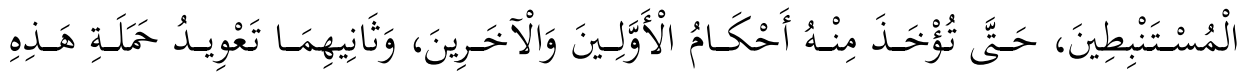

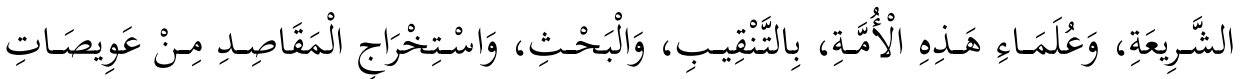

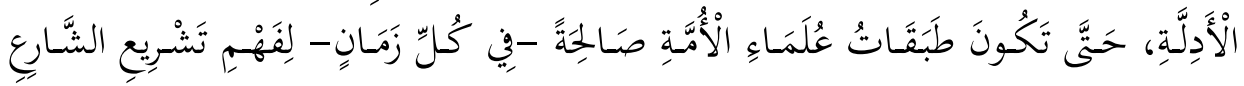

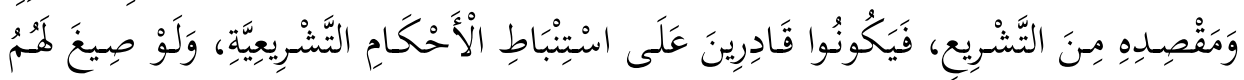

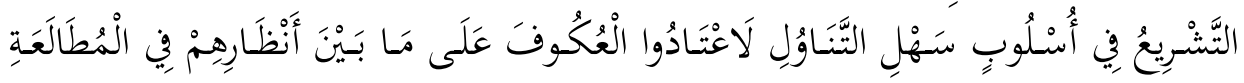

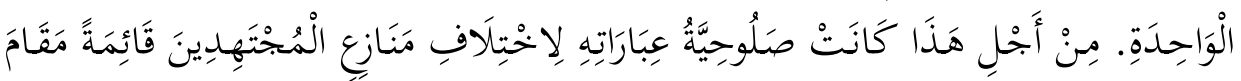

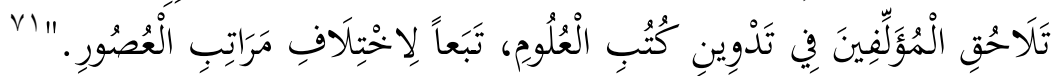

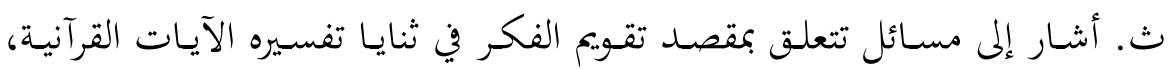

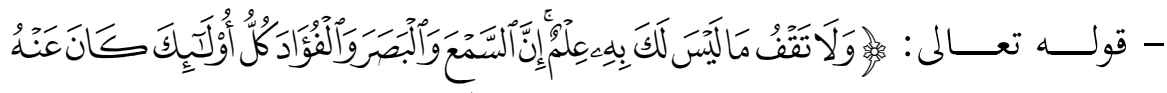

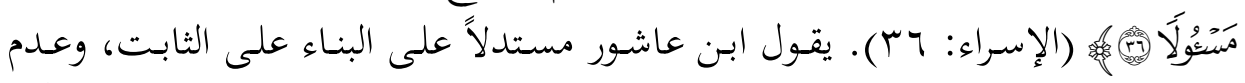

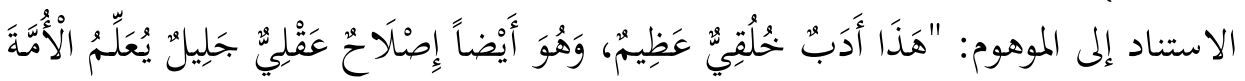

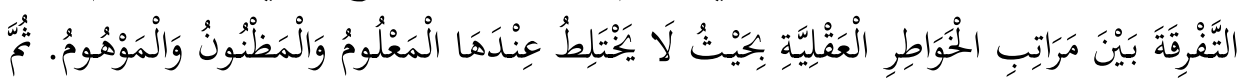

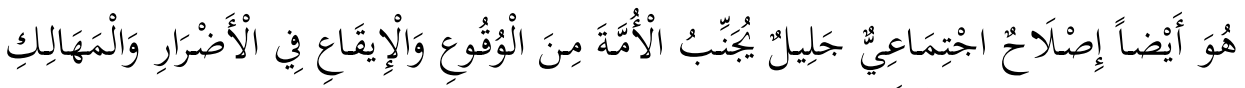

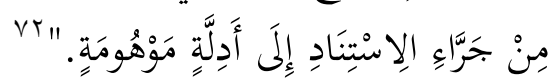

- قولـه تعـالى :

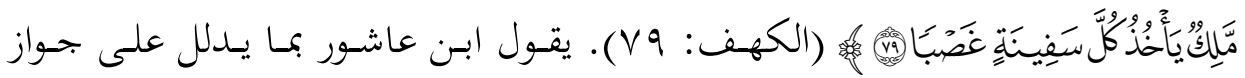

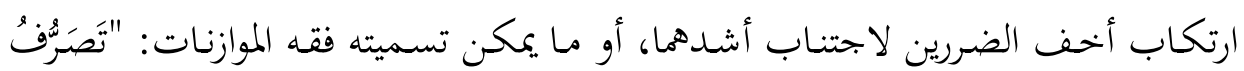

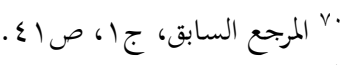

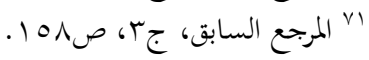

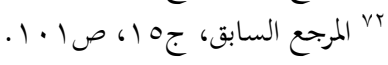




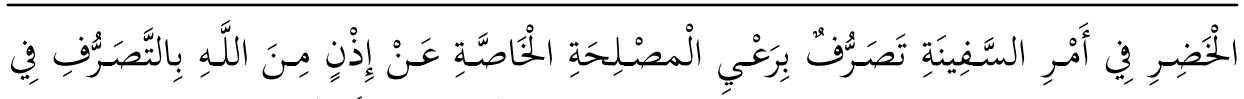

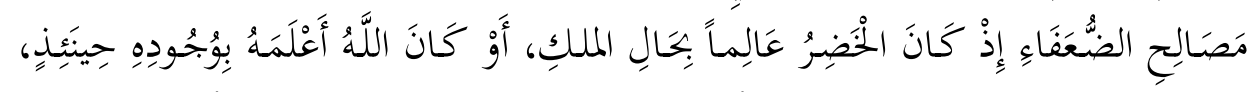

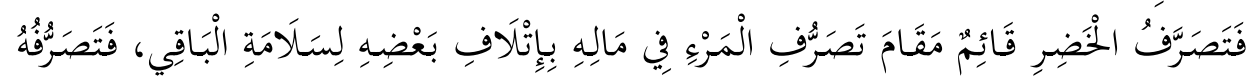

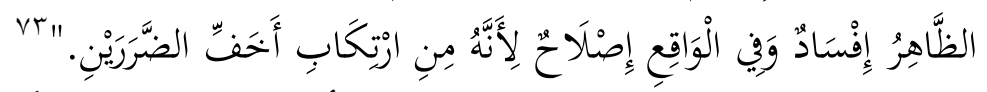

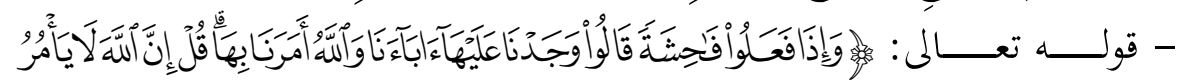

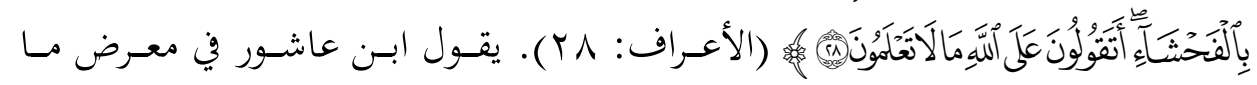

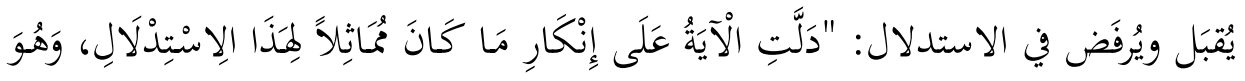

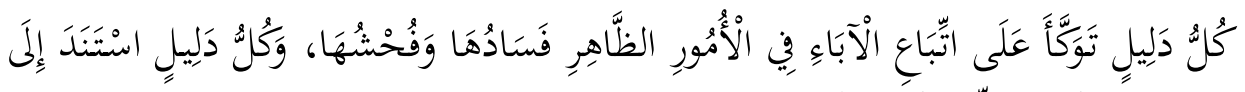

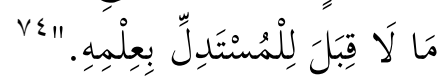

\section{r. مقصد تقويم الفكر عند علال الفاسي:}

يـرى عـلال الفاسي أن وسيلة تحقيق مقاصــ القـرآن هي تقـويم الفكـر؛ إذ قـال:

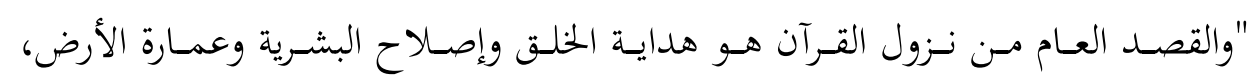

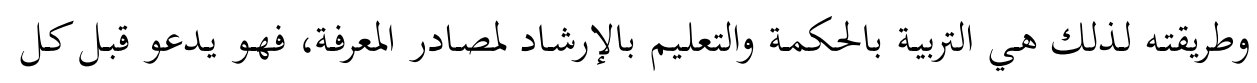

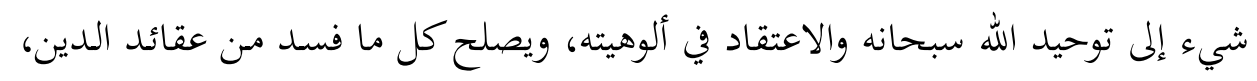

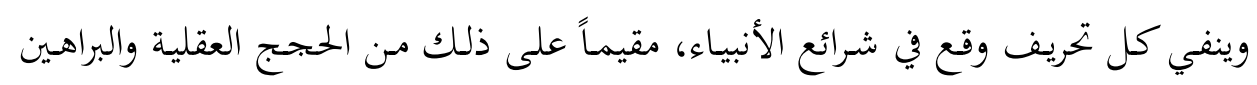

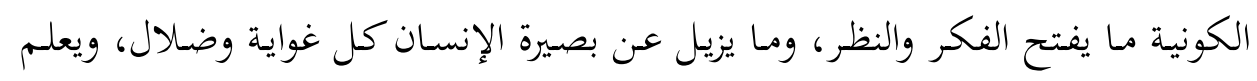

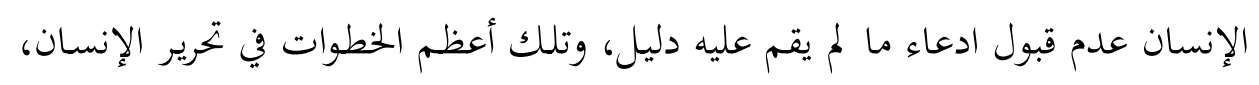

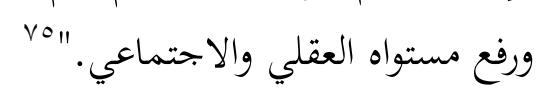

\section{ع. مقصد تقويم الفكر عند سيد قطب:}

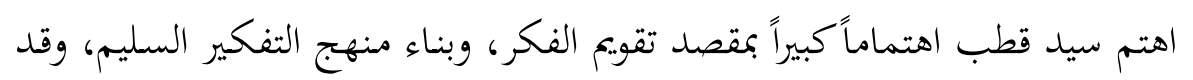

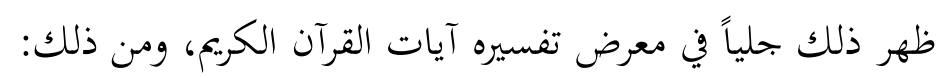

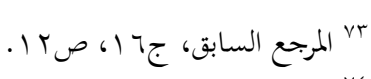

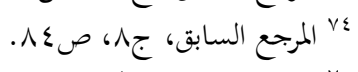

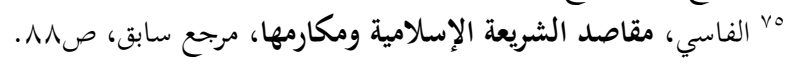




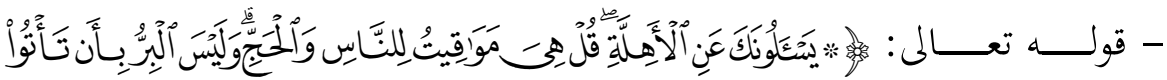

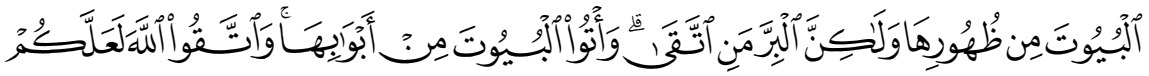

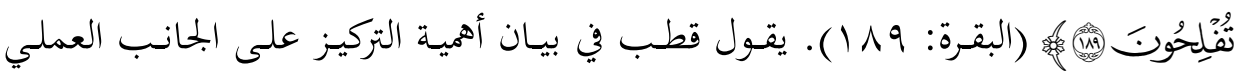

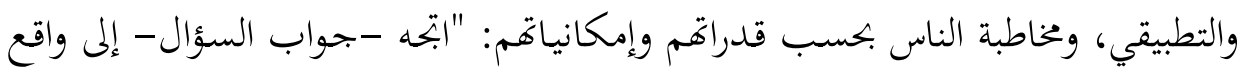

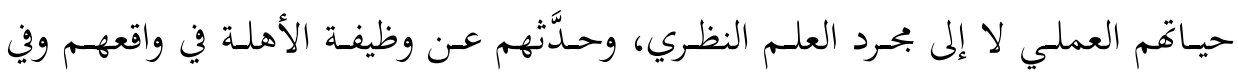

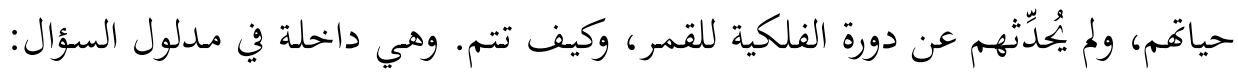

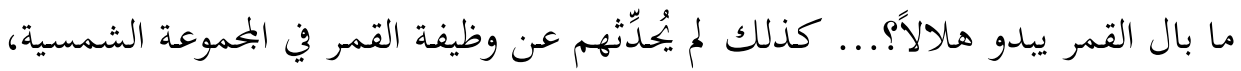

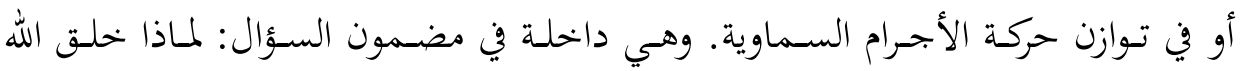

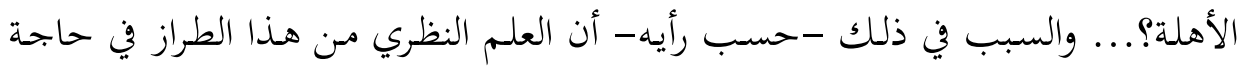

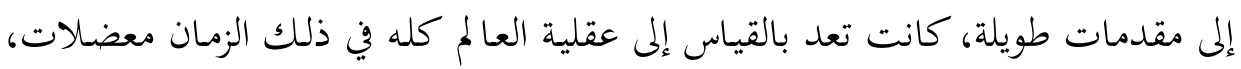

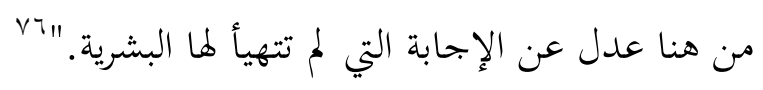

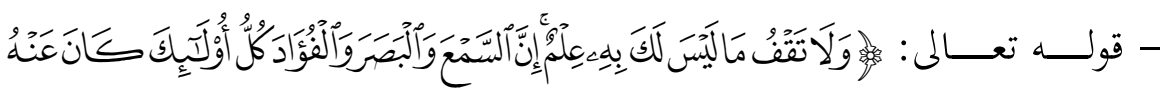

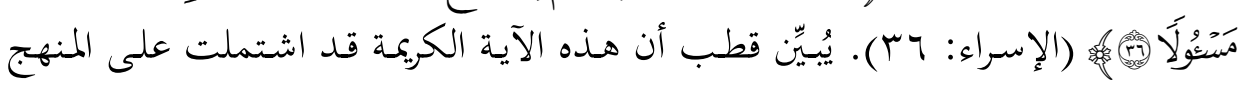

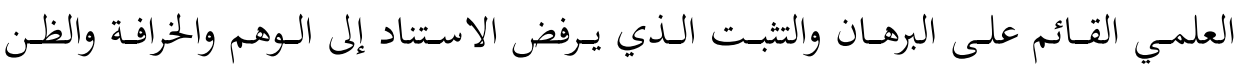

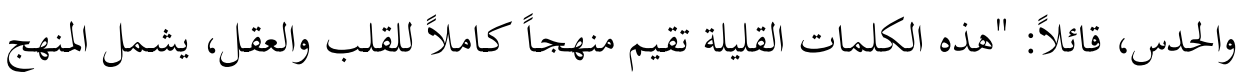

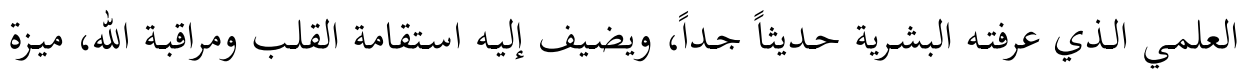

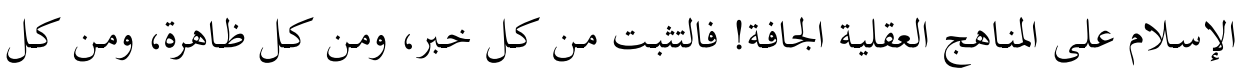

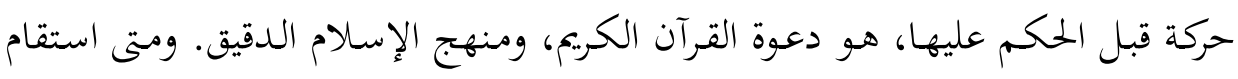

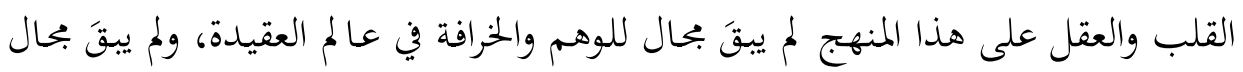

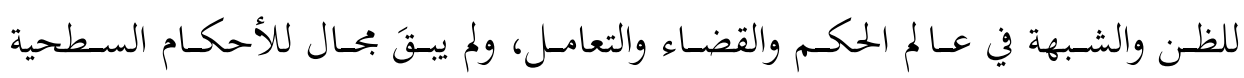

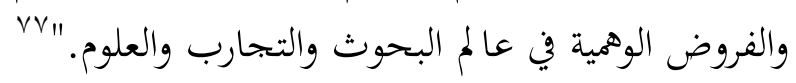

- قوله تعالى :

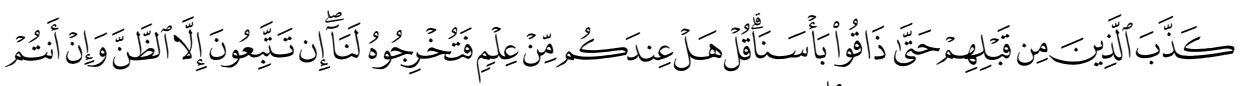

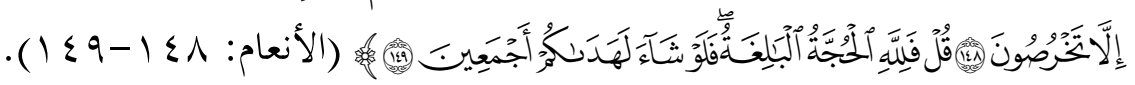

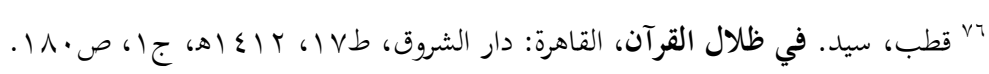

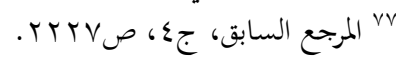


يقول قطب في بيان المنهج القرآني في تصحيح الفكر عند الرد على شبه المشركين

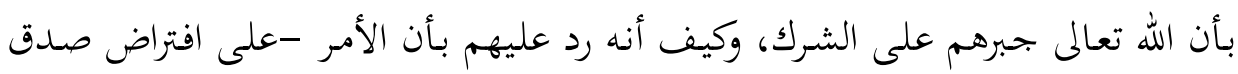

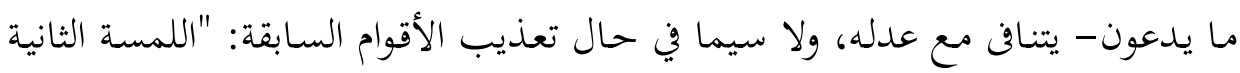

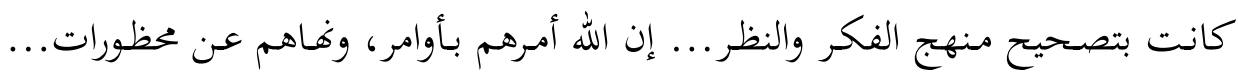

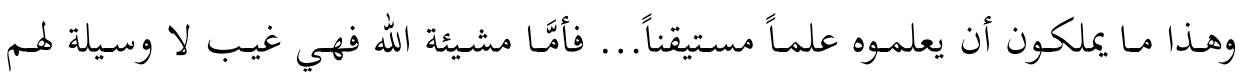

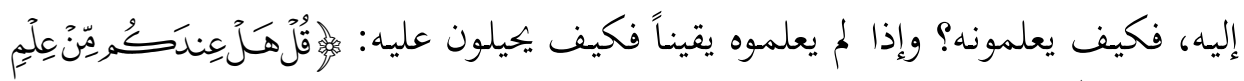

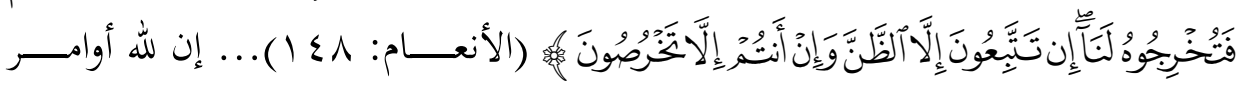

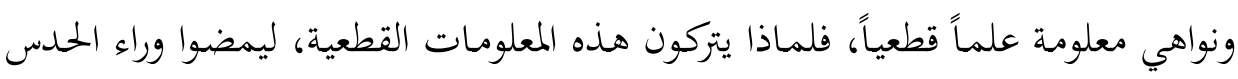

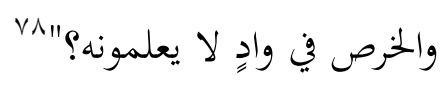

\section{ه. مقصد تقويم الفكر عند أحمد الريسوني:}

عَدَّ الريسوني مقصد تقويم الفكر أحد المقاصد الستة التي يرى أن القرآن الكريم جاء

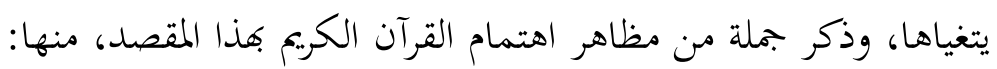

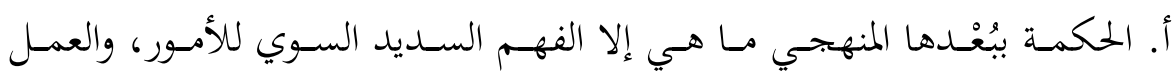
بمقتضى ذلك؛ فالحكمة هي إتقان العلم والعمل، وتنزيل الأقوال والأحكام والأفعال في إلي

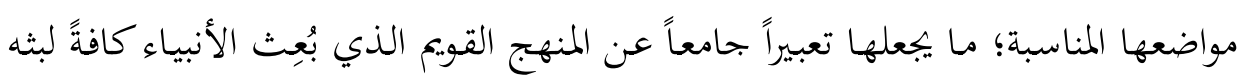

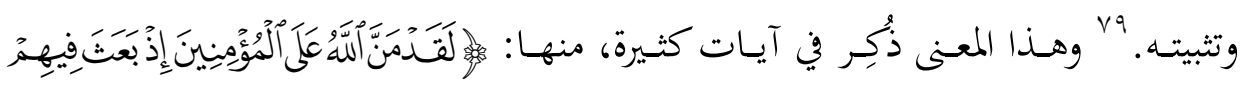

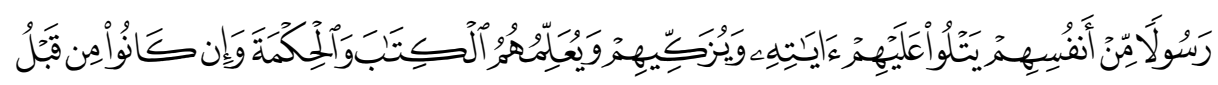

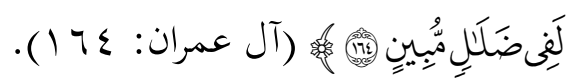

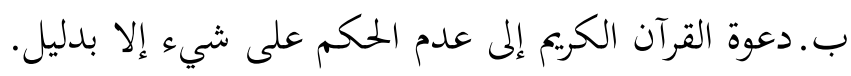

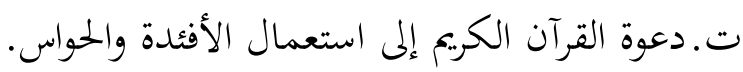

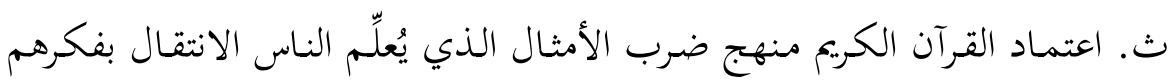

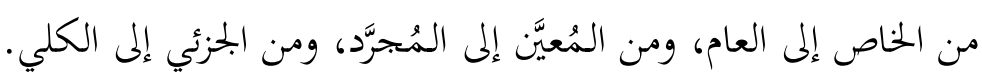


ج. تنبيـه القـرآن الكـيم على مـواطن الخلـل في منهجيـة التفكـير، وهـي: التبعيـة

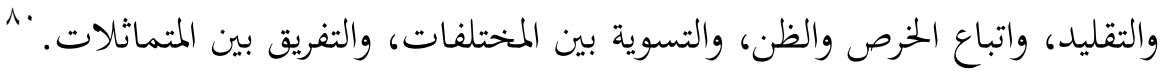

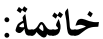

بيَّن البحث أن مقاصد القرآن هي الغايات الكلية التي أُنزل القرآن الكريم لأجلها،

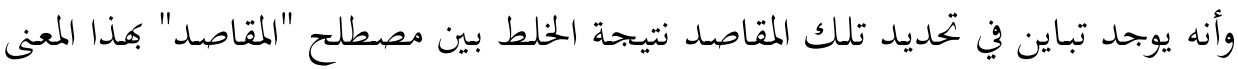

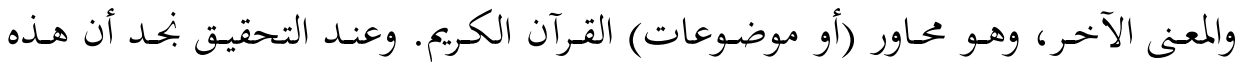

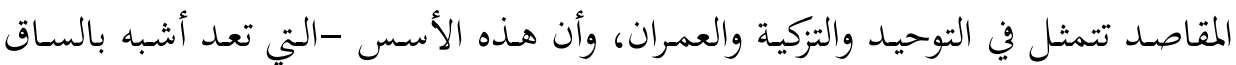
من الشجرة- هي موضع اتفاق في كتابات المعاصرين، وإن كانت بمسميات أخرى. وقد أكد البحث أهمية مقاصد القرآن في النسق المعرفي والحضاري؛ إذ تمثل مقاصد

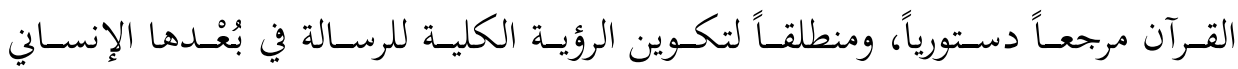

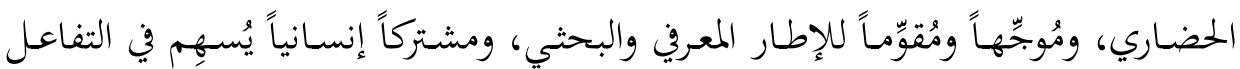
الحضاري.

وتوصـل البحــث إلى أن البنـاء الحضــاري والعمـران لـيس ترفـاً فكريـاً، أو موضـوعاً

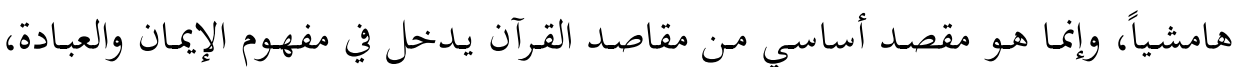

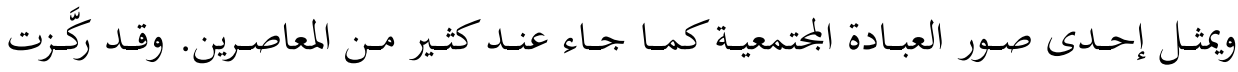

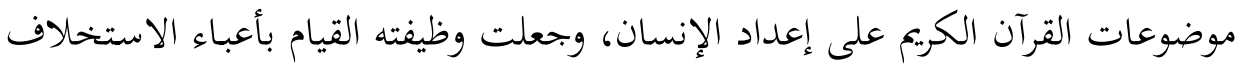
والإعمار عن طريق اكتشاف سنن التسخير، وحسن التعامل معها.

ولا شـك في أن إعمـال المقاصــ القرآنيـة في الواقع المعيش كفيـل بـأن يُحقِّق فوضـاً

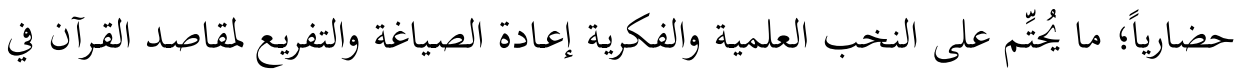

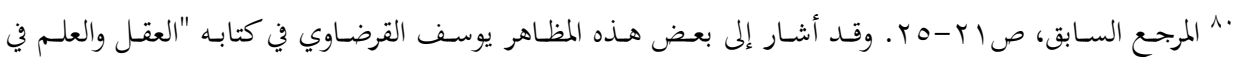

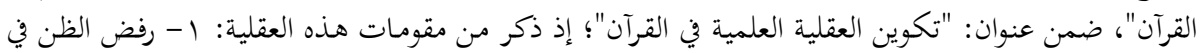

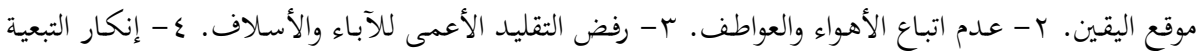

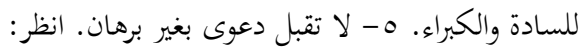

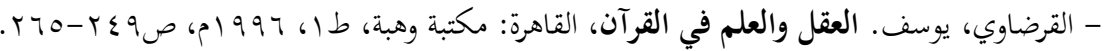


ظل رؤية العالم، لتجد تلك المقاصد مكاها في التنمية البشرية، وتمنح معالم ديننا الحنيف بُعْداً حضارياً، وتُسهِمِ في البناء الإنساني.

وأمَّا تقويم الفكر فيمثل إحدى صور مقاصد القرآن التي تتعلق بالجانب العمراين،

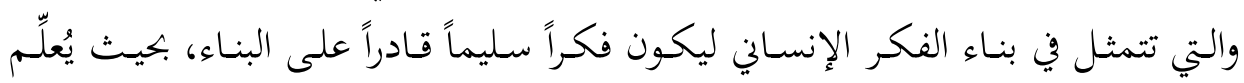

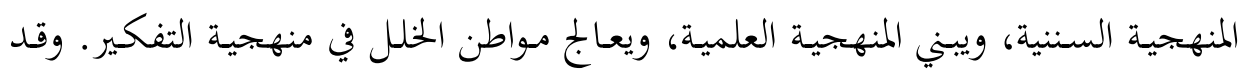

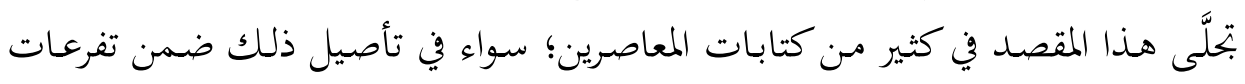

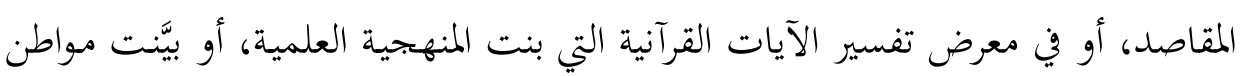
الخلل فيها.

ختاماً، فبإن إعادة صياغة مقاصد القرآن ومقاصد الشريعة في ظل رؤية العالم تمثل

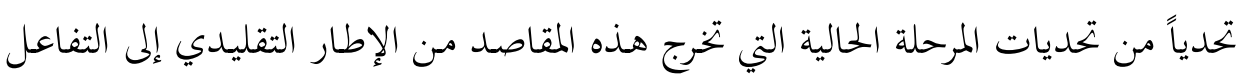

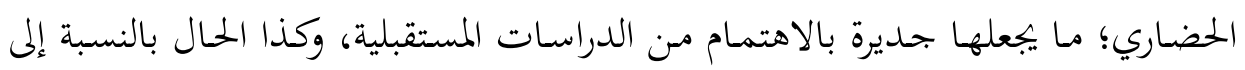

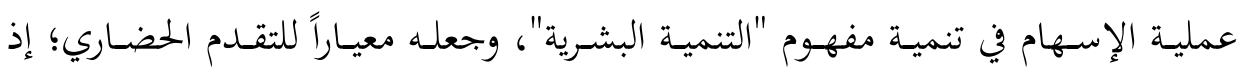

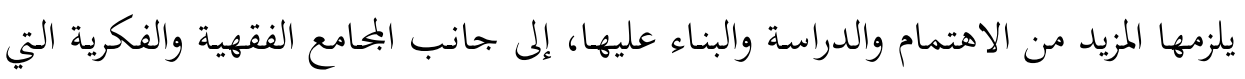
يتعسيَّن عليها إعداد رؤية كونية موحدة بنـاءً على مقاصد القرآن لترسيخ الفكرة الحضارية لإبسالام. 